\title{
Digitalization and Government Corruption in Developing Countries: \\ Towards a Framework and Research Agenda
}

\begin{abstract}
Research focusing on the nexus between digital technologies and government corruption in developing countries has reported mixed findings and painted an incoherent picture. Through a review of 90 relevant studies published over the last two decades we develop an inductive framework that connects 7 defining themes: (1) the broader socioeconomic context of developing countries (2) anti-corruption strategies and strategizing in developing countries (3) digitalization processes (4) strategic role of digital technologies and modalities of anti-corruption change (5) formative structures of government organizations (6) barriers within government organizations and (7) positive and negative effects of digitalization on corruption. Deriving from this framework, we highlight underresearched concerns and outline a research agenda to (1) clarify the links between anticorruption strategizing and digitalization interventions (2) explicate the materialization of corruption in specific organizational domains, work systems, and processes in developing countries, their embedded nature in the organizational and broader context, and the modalities by which digitalization comes to affect or be affected by it (3) uncover digitalization enabled capabilities and dynamic capabilities in the fight against corruption and (4) embrace methodological diversity such as more processual and long-term studies; ethnographic studies, and methods that bridge quantitative and qualitative insights by exploring novel measures and evidence sources.
\end{abstract}

Keywords: Digitalization, Government Corruption, Strategic Information Systems, Developing Countries, Literature Review 


\section{Introduction}

While corruption occurs around the world, it has been shown to be endemic in developing countries and to have particularly harmful effects in government administrations associated with public services and socioeconomic outcomes (Bardhan, 1997; Olken \& Pande, 2012; United Nations Development Program, 2008; World Bank Group, 1998). In the last few decades, strategic information systems implementations and digitalization initiatives of various kinds have been carried out in developing countries to improve services and to stamp out corruption (Kim, Kim, \& Lee, 2009; Neupane, Soar, \& Vaidya, 2012; Silva \& Hirschheim, 2007; Srivastava, Teo, \& Devaraj, 2016; United Nations, 2016). ${ }^{1}$ But despite such interventions in different government administration domains across developing countries, their interplay with corruption remains unclear with mixed and sometimes contradictory findings reported in the relevant literature.

There is limited theorization of the nature of endemic corruption in the government administrations of developing countries, unclear understanding of the relationship between digitalization and government corruption, as well as how and why information systems have not fulfilled their potential in helping to curb corruption in such contexts. In response to these issues, we present an in-depth review of relevant literature from the early period of computerization and the use of internet in developing countries in the 1990s to 2019 to understand the strategic application of digitalization in government reforms and anti-corruption efforts in developing countries. This article (1) takes stock of the current knowledge of digitalization and corruption in developing countries and traces the nature of linkages between the two (2) develops a framework to clarify how and why digitalization has been observed to

\footnotetext{
${ }^{1}$ We use the term digitalization to overcome issues of nomenclature in the literature e.g. studies might refer to ICTs, IT, IS in relation to processes such as innovation, reform, transformation, organizational change etc., all of which invoke the understanding of digitalization as a "range of sociotechnical changes resulting from the adoption of digital technologies" (Legner et al., 2017). We make no distinction between digitalization (digital transformation) and IT transformation given that we consider the organizational context of government primarily (Vial, 2019).
} 
encounter various obstacles in curbing government corruption in developing countries, as well as (3) derives a set of empirical, theoretical and methodological concerns toward an agenda for further work in the area by highlighting under-researched issues and approaches for better understanding the strategic significance of digitalization and its interplay with corruption.

We contribute a framework that systematically integrates current knowledge of digitalization and government corruption in developing countries and highlight avenues for further empirical and theoretical development of the topic. In the next section, a research methodology with details of the literature search, selection, refinement and analysis strategy is presented. We then present findings along with our framework of the linkages between digitalization and government corruption in developing countries and suggestions for further research. Finally, we discuss some limitations of our research and present concluding remarks.

\section{Methods}

We followed a literature review approach that combines systematic literature review and grounded theory coding techniques (Wolfswinkel, Furtmueller, \& Wilderom, 2013). We selected this approach because it ensures "a holistic literature coverage, adequate extraction of meanings and associations between studies as well as thorough analysis" (Senyo, Liu, \& Effah, 2019a). Given our aim of rigorously reviewing the extant literature on digitalisation and corruption, we deemed the selected approach suitable in addressing our research purpose (Figure 1). 


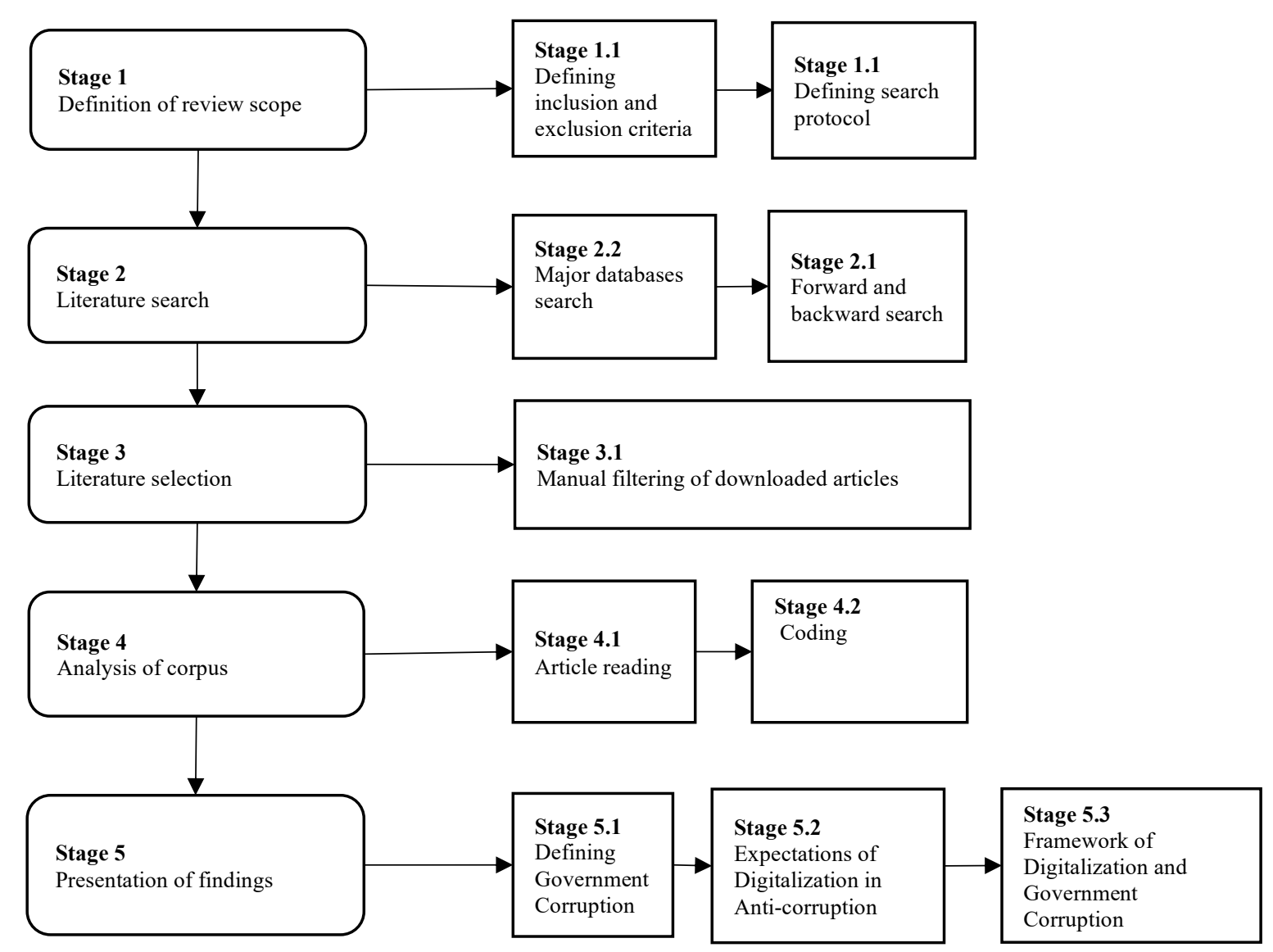

Figure 1: Literature review approach (Adapted from Senyo et al. 2019)

Our review went through five stages: (1) definition of the review's scope (2) literature search (3) literature selection (4) analysis of corpus, and (5) presentation of findings. Appendix 1 provides further details. We began by initially searching four major databases (AIS Library, Scopus, Web of Science and Google Scholar) to understand the coverage of literature and various conceptualisations of digitalisation and corruption in relevant disciplines. Based on the preview of some articles from our initial search, we defined our inclusion and exclusion criteria to primarily cover peer reviewed journals and conference articles. We also defined our search protocol based on combinations of keywords related to "digitalization", "ICT", "information and communication technology", "information system", "information technology", “technology", "developing country" and "corruption". 
In line with our literature inclusion and exclusion criteria and the search protocol, we searched the four major databases to ensure that relevant IS, Management, Public Administration, Development, and ICT4D journals were covered given that digitalization and corruption studies have been published in these disciplines from similar research approaches. For each database search, we downloaded the PDF after reviewing the title, keywords, and abstract of each article. Next, we performed forward and backward searches on the articles downloaded (Jane Webster \& Watson, 2002). From an initial hit of 2,794 articles matching our selected keywords, we obtained a final set of 90 highly relevant empirical studies after applying our inclusion and exclusion criteria and eliminating duplicates and articles without full text.

We then conducted an iterative literature analysis by reading and coding each selected article to extract data and metadata. We derived open codes from each article based on primary research theme and findings relevant to our focus of digitalization and corruption. Next, we iteratively analysed the conceptual similarity between the open codes to derive axial codes. Finally, we derived selective codes by mapping and integrating as well as refining the axial codes to derive higher-order categories. Based on the analysis of data points from the selected articles, we developed a framework of digitalization and government corruption in developing countries. Descriptive stats, full list of works covered in our analysis and our coding approach are provided in the Appendices.

\section{Findings}

Of the 90 papers reviewed, three kinds of research were identified: (1) observational studies of digitalization, corruption, and other variables (2) studies of focal digitalization phenomena in a context of corruption and (3) studies of digitalization as an anti-corruption tool. Observational studies that assess relationships between corruption proxies such as 'corruption perception' or 'control of corruption', digitalization-related variables, and socioeconomic or demographic variables formed the bulk of articles in our sample $(n=42)$. This group is followed by studies 
of focal digitalization phenomena in a context of corruption such as adoption and use, failure, unrealized implementation outcomes of technology $(n=29)$. The last group of relatively few papers explicitly explore the role of digitalization as an anti-corruption tool $(n=19)$. Table 1 describes features of the three kinds of research.

\begin{tabular}{|l|l|}
\hline Research & Description \\
\hline $\begin{array}{l}\text { Observational studies of } \\
\text { digitalization, corruption, } \\
\text { and other variables }\end{array}$ & $\begin{array}{l}\text { Quantitative studies that adopt statistical or econometric approaches to draw inferences or to } \\
\text { establish relationships between variables. They assess relationships between corruption } \\
\text { proxies such as 'corruption perception' or 'control of corruption', digitalization-related } \\
\text { variables, and socioeconomic or demographic variables. Studies commonly exploit publicly } \\
\text { available cross-country corruption data e.g., Transparency International's corruption } \\
\text { perceptions index (CPI), and the World Bank's control of corruption index (CCI), to test } \\
\text { hypotheses that may or may not be sensitized by theory, or to develop explanations. } \\
\text { Corruption related datasets are combined-as dependent or independent variables-with } \\
\text { datasets on digitalization and related variables to assess associations, and less commonly, } \\
\text { causation. }\end{array}$ \\
\hline $\begin{array}{l}\text { Studies of focal } \\
\text { digitalization phenomena } \\
\text { in a context of corruption }\end{array}$ & $\begin{array}{l}\text { Mostly qualitative case studies where consideration of corruption is not sustained, and } \\
\text { comes up only in relation to some focal digitalization phenomena such as adoption and use, } \\
\text { failure, unrealized implementation outcomes, etc. }\end{array}$ \\
\hline $\begin{array}{l}\text { Studies of digitalization } \\
\text { as an anti-corruption tool }\end{array}$ & $\begin{array}{l}\text { Mostly qualitative studies that explore the question of whether and how digitalization might } \\
\text { work as an anti-corruption tool. A frequent thread in such research is the role of technology } \\
\text { in enabling transparency and accountability, based on a theoretical assumption that } \\
\text { corruption arises from the agency problem, manifesting through information asymmetry and } \\
\text { unchecked monopoly power. Corruption is not considered directly in such studies (largely } \\
\text { due to methodological and empirical constraints of observing and measuring corruption) but } \\
\text { through perceptions of it, or in relation to the potential role of digital technologies in its } \\
\text { constraint, such as for transparency, accountability, or some other means (rather than an } \\
\text { actual role observed in empirical settings). }\end{array}$ \\
\hline
\end{tabular}

Table 1: Approaches to research on digitalization and government corruption

Next, we discuss elements of the analysis from our full sample before focusing on the subset of qualitative case studies that provide more details for understanding the 'how' and 'why' of digitalization and government corruption in developing countries. Our framework is derived from the latter subset of papers (studies of focal digitalization phenomena in a context of corruption and studies of digitalization as an anti-corruption tool $(\mathrm{n}=48))$.

\subsection{Government corruption}

We began our analysis by assessing how corruption is defined and framed as well as understandings of government corruption in the literature (de Graft, 2007). From our sample, we identified various definitions in use (Table 2).

\begin{tabular}{|l|l|}
\hline Definition & Study \\
\hline $\begin{array}{l}\text { Abuse/misuse of (public) power for private/personal gain } \\
(\mathrm{n}=17)\end{array}$ & $\begin{array}{l}\text { Andersen 2009, Bhuiyan 2011, Charoensukmongkol } \\
\text { and Moqbel 2014, Elbahnasawy 2014 }\end{array}$ \\
& Kim 2014, Kim et al. 2009, Kock and Gaskins 2014, \\
& Lio et al. 2011, Neupane, Soar, and Vaidya 2014, \\
& Neupane, Soar, and Vaidya 2015, Pathak et al. 2009, \\
\hline
\end{tabular}




\begin{tabular}{|c|c|}
\hline & $\begin{array}{l}\text { Shrivastava and Bhattacherjee 2014, Shrivastava and } \\
\text { Bhattacherjee 2015, Soper 2007, Srivastava et al. } \\
\text { 2016, Twinomurinzi et al 2011, Walle at al } 2018 \\
\end{array}$ \\
\hline $\begin{array}{l}\text { Abuse/misuse of (public) office for private/ personal gain } \\
(\mathrm{n}=15)\end{array}$ & $\begin{array}{l}\text { Addo 2018, Bhattacherjee and Shrivastava 2018, } \\
\text { Corojan and Criado 2012, Hope and Korpoe 2011, } \\
\text { Khan and Krishnan 2018, Kock and Gaskins 2013, } \\
\text { Krishnan et al 2012, Martinez 2015, Neupane et al. } \\
\text { 2012, Oni 2016, Ramasoota 1998, Relly 2012, Saxena } \\
\text { 2017, Selke et al. 2008, Silal et al 2019, Syed et al } \\
\text { 2019, Xinli 2015 }\end{array}$ \\
\hline Corruption perception $(\mathrm{n}=15)$ & $\begin{array}{l}\text { DiRienzo et al. 2007, Jha and Sarangi 2017, Kovacic } \\
\text { 2005, Krishnan et al. 2013, Mimbi and Bankole 2016, } \\
\text { Mistry 2012, Mistry and Jalal 2012, Nugroho 2014, } \\
\text { Prasad and Shivarajan 2015, Sassi and Ben Ali 2017, } \\
\text { Shim and Eom 2008, Shim and Eom 2009, Shrivastava } \\
\text { and Bhattacherjee 2014, Shrivastava and Bhattacherjee } \\
\text { 2015, Zhao et al. 2017 }\end{array}$ \\
\hline $\begin{array}{l}\text { Behavior that "deviates from the formal duties of a public role } \\
\text { because of private-regarding (personal, close family, private } \\
\text { clique) pecuniary or status gains; or violates rules against the } \\
\text { exercise of certain private-regarding behavior" (Klitgaard, } \\
1988, \text { p. 23) }\end{array}$ & Bailard 2009 \\
\hline $\begin{array}{l}\text { Illegal activity in which power (goods and services) holders } \\
\text { provide "favors" for a "fee" to those who find the legal route } \\
\text { more costly. Corruption involves acts in which a public office } \\
\text { is used to enhance a public officer's personal interests, in a } \\
\text { manner that goes against the rules of the office (Jain, 2001) }\end{array}$ & Garcia-Murillo 2013 \\
\hline Reported corruption & Davis 2004 \\
\hline Collective action problem & Kossow and Kukutschka 2017 \\
\hline $\begin{array}{l}\text { Decision makers, politicians and other owners of public offices } \\
\text { deliberately distort economic policies to support and carry } \\
\text { forward their own personal interests, Compromise and infringe } \\
\text { impartiality principles for realizing personal benefits. }\end{array}$ & Sahay and Puri 2008 \\
\hline $\begin{array}{l}\text { Inducement to wrong by bribery or other unlawful or improper } \\
\text { means }(n=1)\end{array}$ & Heeks 1998 \\
\hline $\begin{array}{l}\text { Misuse of a public or private position for direct or indirect } \\
\text { personal gain. }(\mathrm{n}=1)\end{array}$ & Kanyam et al. 2017 \\
\hline $\begin{array}{l}\text { Misuse of entrusted authority for private gain (usually focuses } \\
\text { on abuse of power in public sector) (UNDP, 2008) }\end{array}$ & Abu-Shanab et al. 2013 \\
\hline $\begin{array}{l}\text { Departure of public officials from rules and norms for private } \\
\text { gains (Warren 2004) }\end{array}$ & Choi 2014 \\
\hline $\begin{array}{l}\text { Offering of bribes to public sector officials and the acceptance } \\
\text { of such bribes (p.349) }\end{array}$ & Mahmood 2004 \\
\hline $\begin{array}{l}\text { Expression of rent-seeking, patrimonialism, and } \\
\text { neopatrimonialism }(\mathrm{n}=1)\end{array}$ & Addo 2016 \\
\hline $\begin{array}{l}\text { Extortion, fraud, injustice, nobble, influence peddling, illegal } \\
\text { payments and money laundering }\end{array}$ & Valle-Cruz et al. 2016 \\
\hline $\begin{array}{l}\text { Illegal act by definition (McMullan 1961, p.184). Corruption as } \\
\text { exploiting public authority for private gains (Aladwani, 2016) }\end{array}$ & Nam 2018 \\
\hline Not clearly stated $(\mathrm{n}=30)$ & $\begin{array}{l}\text { Alryalat at al 2013, Amankwah-Safo et al 2018, } \\
\text { Ameen and Ahmad 2013, Bellini 2014, Berman and } \\
\text { Tettey 2001, Cho and Choi 2004, Choudrie et al. 2017, } \\
\text { Goundar 2009, Introna et al. 2010, Krishnan and Teo } \\
\text { 2012, Lee and Lio 2016, Masiero 2015, Owusu-Oware } \\
\text { et al 2018, Palvia et al 2017, Pankowska 2017, } \\
\text { Peterson 1998, Priyatman 2008, Raghupathi and Wu } \\
\text { 2011, Rana et al 2013, Rana et al 2014, Senyo et al } \\
\text { 2019, Seo and Warman 2011, Silva and Hirschheim } \\
\text { 2007, Srivastava et al 2007, Stamati et al. 2015, } \\
\text { Stremlau et al. 2015, Therese and Azwe 2016, Vaidya } \\
\text { and Myers 2017, Veeraraghavan 2013, Zhao and Xu } \\
\text { 2015 }\end{array}$ \\
\hline
\end{tabular}

Table 2: Definitions of government corruption adopted in the reviewed literature 
A majority of studies $(n=30)$ take corruption as a given and do not explicate a working definition. Others adopt corruption perception and related proxies that black box the phenomena $(n=15)$. Of the studies that state a definition, most $(n=32)$ adopt the commonest definition of corruption in circulation - the abuse/misuse of public power $(n=17)$ or office $(n=15)$ for private/personal gain. Although this dominant definition has the merit of encompassing an otherwise complex and multifaceted phenomena comprising different types of actions, behaviours and practices, it suffers from a lack of conceptual clarity and specificity. For example, the definition relies on a clear distinction between 'public' and 'private' although in the context of several developing countries, particularly those in Africa, it has been shown that the lines between public and private are at best blurred and at worst non-existent (Nawaz \& Hodess, 2008; O’Neil, 2007; von Soest, 2006).

Furthermore, the dominant definition appears abstract without making concrete what constitutes 'abuse/misuse', what is privately gained and by whom, and whether such private gains are necessarily against the public interest (if one considers the public as a collection of individuals who might assume contingent roles and affinities that supersede their general public membership). For example, in certain developing countries where nepotism and similar corruption are rife, organizational affinities like family and clan appear more salient than an abstract sense of publicness but tacit arrangements might be in place to ensure benefits are fairly rationed rather than hoarded by particular groups (Joseph, 1987, 1996). Furthermore, it has been shown that in many developing countries, public sector corruption is not the preserve of public officials but is actively and beneficially indulged in by private citizens and members of the public who induce government officials (Ufere \& Carlson, 2012).

It is also notable that the dominant definition of corruption covers such a wide range of different practices involving one (e.g. theft, self-dealing, sabotage), two (bribery, speedmoney, kick-backs) or more individuals (racketeering, influence peddling, collusion), that by 
appearing to describe everything it ends up describing nothing really well. For example, the various practices used to instantiate the dominant definition in case studies do not have normative equivalence or universal consideration as equally wrong; theft or fraud might be considered as wrong in many places but influence peddling or bribery might be sociocultural and context specific with more acceptability in certain places than in others where local norms do not permit (Hasty, 2005). In essence, the public-private dichotomy underlying the dominant definition of corruption is not as universal nor as clean-cut as might appear and has shifting western-centric connotations and normativity (Anter, 2014; Antonsen \& Beck Jørgensen, 1997) that struggle against everyday realities in developing countries.

Other definitions that attempt specificity appear to fall into circularity as they are based on, rather than independent of, assumptions in the study and thereby violate elements of clear conceptual definition (Suddaby, 2010). Such conceptual unclarity qua circularity typically takes the form 'corruption is defined/conceptualized as $\mathrm{X}$ because our study shows $\mathrm{X}$ '. For example, Kossow \& Kukutcha (2017) conceptualize corruption as a collective action problem for the purpose of explaining the relationship between ICT and corruption control through the empowering of citizens and support of civil society. Addo (2018) conceptualized (petty) government corruption as opportunistic crime to explain the role of technology in removing corruption inducing opportunities.

To get a clearer picture of the phenomena of government corruption from the literature, we further examined the various levels of analysis and corrupt entities targeted for or associated with digital intervention (Table 3).

\begin{tabular}{|c|c|c|}
\hline Type of study & Level of analysis & Study \\
\hline $\begin{array}{l}\text { Observational studies of } \\
\text { digitalization, corruption } \\
\text { and additional variables } \\
(n=42)\end{array}$ & Cross-country $(n=35)$ & $\begin{array}{l}\text { Andersen 2009, Bhattacherjee and Shrivastava 2018, Charoensukmongkol } \\
\text { and Moqbel 2014, Choi 2014, DiRienzo et al. 2007, Elbahnasawy 2014, } \\
\text { Garcia-Murillo 2013, Hope and Korpoe 2011, Jha and Sarangi 2017, Kanyam } \\
\text { et al. 2017, Khan and Krishnan 2018, Kim 2014, Kossow and Kukutschka } \\
\text { 2017, Kovacic 2005, Krishnan and Teo 2012, Krishnan et al 2012, Krishnan et } \\
\text { al. 2013, Lio et al. 2011, Mimbi and Bankole 2016, Mistry 2012, Mistry and } \\
\text { Jalal 2012, Nam 2018, Raghupathi and Wu 2011, Sassi and Ben Ali 2017, } \\
\text { Shim and Eom 2008, Shim and Eom 2009, Shrivastava and Bhattacherjee } \\
\text { 2014, Shrivastava and Bhattacherjee 2015, Soper 2007, Srivastava et al 2007, } \\
\text { Srivastava et al. 2016, Twinomurinzi et al 2011, Walle at al 2018, Zhao and Xu } \\
\text { 2015, Zhao et al. } 2017\end{array}$ \\
\hline
\end{tabular}




\begin{tabular}{|c|c|c|}
\hline & National $(n=6)$ & $\begin{array}{l}\text { Abu-Shanab et al. 2013, Alryalat at al 2013, Bailard 2009, Neupane et al. } \\
2012 \text {, Saxena 2017, Valle-Cruz et al. } 2016\end{array}$ \\
\hline & Organizational $(n=1)$ & Neupane, Soar, and Vaidya 2014 \\
\hline \multirow{7}{*}{$\begin{array}{l}\text { Studies of focal } \\
\text { digitalization } \\
\text { phenomena in a context } \\
\text { of corruption }(n=29)\end{array}$} & Organizational $(n=12)$ & $\begin{array}{l}\text { Addo 2016, Amankwah-Safo et al 2018, Ameen and Ahmad 2013, Davis 2004, } \\
\text { Heeks 1998, Introna et al. 2010, Martinez 2015, Neupane, Soar, and Vaidya } \\
\text { 2015, Senyo et al 2019, Vaidya and Myers 2017, Xinli } 2015\end{array}$ \\
\hline & National $(n=11)$ & $\begin{array}{l}\text { Cho and Choi 2004, Choudrie et al. 2017, Goundar 2009, Mahmood 2004, } \\
\text { Nugroho 2014, Oni 2016, Pathak et al. 2009, Peterson 1998, Rana et al 2013, } \\
\text { Silal et al 2019, Silva and Hirschheim 2007, Berman and Tettey } 2001\end{array}$ \\
\hline & Group/Team $(n=2)$ & Seo and Warman 2011, Therese and Azwe 2016 \\
\hline & Transactions & Prasad and Shivarajan 2015 \\
\hline & Individual & Rana et al 2014 \\
\hline & State & Masiero 2015 \\
\hline & Process & Priyatman 2008 \\
\hline \multirow{7}{*}{$\begin{array}{l}\text { Studies of digitalization } \\
\text { as an anti-corruption } \\
\text { tool }(n=19)\end{array}$} & National $(n=7)$ & $\begin{array}{l}\text { Bhuiyan 2011, Corojan and Criado 2012, Kim et al. 2009, Owusu, Oware et al } \\
\text { 2018, Ramasoota 1998, Stamati et al. 2015, Stremlau et al. } 2015\end{array}$ \\
\hline & Organizational $(n=4)$ & Addo 2018, Sahay and Puri 2008, Syed et al 2019, Veeraraghavan 2013 \\
\hline & Work system $(n=2)$ & Bellini 2014, Pankowska 2017 \\
\hline & Provincial & Lee and Lio 2016 \\
\hline & Cross-country $(n=3)$ & Kock and Gaskins 2013, Kock and Gaskins 2014, Relly 2012 \\
\hline & Community & Selke et al. 2008 \\
\hline & $\mathrm{n} / \mathrm{a}$ & Palvia et al 2017 \\
\hline
\end{tabular}

Table 3: Level of analysis associated with digitalization and corruption

Observational studies consider corruption at the national or cross-country level with less specificity on the range of corruption types at stake or their materialization in specific settings.

As a result, there is limited understanding of the nature and mechanics of corruption at the organisational, national and cross-country levels in such studies. Studies that focus on digitalization phenomena in a context of corruption investigate corruption at the organisational, national, group/team, transactions, individual, state and process levels. Similarly, these studies also provide scant details about the nature of corruption in terms of its definition and framing. Studies of digitalization as an anti-corruption tool also consider corruption at the national, organizational, work system, provincial, cross-country and community levels. These studies consider individuals and their practices, corruption within group and teams, corruption at the level of work process, within particular government administrations/agencies, across government administrations/agencies or at the societal level.

\subsection{Expectations of digitalization in relation to corruption}

Numerous studies of digitalization and corruption present optimism about the implications of digitalization for anti-corruption. However, on closer inspection, this often proves to be based merely on expectation of the potential of digital technologies rather than their demonstrated 
effects in particular settings. IS and related disciplines caution against conflation of the potential effects of technology with its actual effects in situated contexts since technologyenabled change is sociotechnical and shaped by contingencies in the organizational and broader environment (Avgerou \& Addo, 2017; Orlikowski \& Baroudi, 1991; Sawyer \& Jarrahi, 2014). Sensitized by such distinction between expectations and outcomes, we first trace the expectations underpinning digitalization for anti-corruption or within government corruption contexts (Table 4).

\begin{tabular}{|c|c|c|c|}
\hline Digitalization & $\begin{array}{l}\text { Expectations of Digitalization in } \\
\text { Anti-corruption }\end{array}$ & Example technologies used & Study \\
\hline \multirow{22}{*}{$\begin{array}{l}\text { ICT/IT/Information } \\
\text { system } \\
\text { (unspecified) } \\
(\mathrm{n}=29)\end{array}$} & \multirow{10}{*}{$\begin{array}{l}\text { IT can enable improved business } \\
\text { processes which might lead to } \\
\text { reduction in corruption }\end{array}$} & Citizen service centers & Introna et al. 2010 \\
\hline & & $\begin{array}{l}\text { Digitalized public distribution } \\
\text { system (PDS) }\end{array}$ & Masiero 2015 \\
\hline & & E-government services & $\begin{array}{l}\text { Krishnan and Teo 2012, Krishnan et } \\
\text { al } 2012\end{array}$ \\
\hline & & $\begin{array}{l}\text { Electronic district (E-district) } \\
\text { system }\end{array}$ & Rana et al 2014 \\
\hline & & $\begin{array}{l}\text { e-Revenue Licence system at } \\
\text { Department of Motor Traffic } \\
\text { (DMT) }\end{array}$ & Syed et al 2019 \\
\hline & & $\begin{array}{l}\text { Free software implemented by } \\
\text { a not for profit NGO) for the } \\
\text { public health sector in an Indian } \\
\text { state }\end{array}$ & Sahay and Puri 2008 \\
\hline & & $\begin{array}{l}\text { Management system of 'holding } \\
\text { tax' }\end{array}$ & Selke et al. 2008 \\
\hline & & $\begin{array}{l}\text { Personnel system, accounting } \\
\text { system etc. }\end{array}$ & Peterson 1998 \\
\hline & & $\begin{array}{l}\text { Seat/berth reservation system, } \\
\text { payroll system, university marks } \\
\text { information system, university } \\
\text { admissions information system, } \\
\text { importer database }\end{array}$ & Heeks 1998 \\
\hline & & TradeNet, GCMS, PAARS & $\begin{array}{l}\text { Amankwah-Safo et al } 2018 \text {, Senyo } \\
\text { et al } 2019\end{array}$ \\
\hline & \multirow{6}{*}{$\begin{array}{l}\text { IT can enable transparency and } \\
\text { monitoring which might lead to } \\
\text { reduction in corruption }\end{array}$} & E-government services & Silal et al 2019 \\
\hline & & $\begin{array}{l}\text { Electronic Monitoring System } \\
\text { (EMS) }\end{array}$ & Xinli 2015 \\
\hline & & E-procurement system & $\begin{array}{l}\text { Neupane, Soar, and Vaidya } 2015, \\
\text { Nugroho } 2014 \text {, Seo and Warman } \\
2011\end{array}$ \\
\hline & & $\begin{array}{l}\text { Financial information systems } \\
\text { (FIS) }\end{array}$ & Ameen and Ahmad 2013 \\
\hline & & $\begin{array}{l}\text { Information and monitoring } \\
\text { systems }\end{array}$ & Davis 2004, Veeraraghavan 2013 \\
\hline & & $\begin{array}{l}\text { Internal systems (Intsys), SIAFI, } \\
\text { telephone, word document etc. }\end{array}$ & Martinez 2015 \\
\hline & & & $\begin{array}{l}\text { Berman and Tettey 2001, Mahmood } \\
\text { 2004, Vaidya and Myers } 2017\end{array}$ \\
\hline & ICT use can help deter corruption & & Bhattacherjee and Shrivastava 2018 \\
\hline & $\begin{array}{l}\text { ICT development in a country helps } \\
\text { reduce corruption }\end{array}$ & & Shrivastava and Bhattacherjee 2014 \\
\hline & $\begin{array}{l}\text { To drive implementation of } \\
\text { development projects to curb } \\
\text { corruption }\end{array}$ & & Therese and Azwe 2016 \\
\hline & $\begin{array}{l}\text { ICT penetration and penalty for } \\
\text { corruption control }\end{array}$ & & Shrivastava and Bhattacherjee 2015 \\
\hline & $\begin{array}{l}\text { IT enables transparency which } \\
\text { helps reduce corruption }\end{array}$ & & Pathak et al. 2009 \\
\hline Computing $(n=7)$ & $\begin{array}{l}\text { IT can enable transparency and } \\
\text { monitoring which might lead to } \\
\text { reduction in corruption }\end{array}$ & $\begin{array}{l}\text { Enterprise architecture } \\
\text { language, Archimate, for public } \\
\text { sector procurement process } \\
\text { modelling }\end{array}$ & Pankowska 2017 \\
\hline
\end{tabular}




\begin{tabular}{|c|c|c|c|}
\hline & & $\begin{array}{l}\text { OPEN (Online Procedures } \\
\text { ENhancement for civil } \\
\text { application) }\end{array}$ & Cho and Choi 2004, Kim et al. 2009 \\
\hline & & $\begin{array}{l}\text { OPEN (Online Procedures } \\
\text { ENhancement for civil } \\
\text { application), Gyandoot } \\
\text { (community network system) }\end{array}$ & Bhuiyan 2011 \\
\hline & IT can enable improved business & ERP & Choudrie et al. 2017 \\
\hline & $\begin{array}{l}\text { processes which might lead to } \\
\text { reduction in corruption }\end{array}$ & TradeNet & Addo 2016 \\
\hline & $\begin{array}{l}\text { Social media enables openness } \\
\text { and accountability }\end{array}$ & $\begin{array}{l}\text { Social Media, registers and web } \\
\text { sources }\end{array}$ & Bellini 2014 \\
\hline $\begin{array}{l}\text { Connectivity } \\
(\mathrm{n}=7)\end{array}$ & $\begin{array}{l}\text { Empower citizens to fight } \\
\text { corruption, as tool to engage } \\
\text { actively online to unseat powerful } \\
\text { actors }\end{array}$ & Mobile platforms & Twinomurinzi et al 2011 \\
\hline & $\begin{array}{l}\text { Corruption hinders e-government } \\
\text { maturity }\end{array}$ & Online services & Khan and Krishnan 2018 \\
\hline & $\begin{array}{l}\text { IT might lower transaction costs } \\
\text { which might reduce corruption }\end{array}$ & Government websites & Prasad and Shivarajan 2015 \\
\hline & $\begin{array}{l}\text { Social media enables openness } \\
\text { and accountability }\end{array}$ & Social Media & Stamati et al. 2015 \\
\hline & $\begin{array}{l}\text { Internet diffusion enables voice and } \\
\text { accountability for corruption }\end{array}$ & Internet & Kock and Gaskins 2013 \\
\hline & $\begin{array}{l}\text { Improved connectivity via internet } \\
\text { and mobile helps reduce corruption }\end{array}$ & Internet, cell phone & Relly 2012 \\
\hline & $\begin{array}{l}\text { IT can enable improved business } \\
\text { processes which might lead to } \\
\text { reduction in corruption }\end{array}$ & TradeNet, GCMS & Addo 2018 \\
\hline Information $(\mathrm{n}=6)$ & $\begin{array}{l}\text { IT can enable transparency and } \\
\text { monitoring which might lead to } \\
\text { reduction in corruption }\end{array}$ & $\begin{array}{l}\text { Population information network } \\
\text { (PIN) }\end{array}$ & Ramasoota 1998 \\
\hline & $\begin{array}{l}\text { Media through radio can help hold } \\
\text { power holders to account and } \\
\text { thereby reduce corruption }\end{array}$ & Radio & Stremlau et al. 2015 \\
\hline & $\begin{array}{l}\text { Improve information (validate } \\
\text { identities) to reduce corruption }\end{array}$ & Biometric technology & Owusu-Oware et al 2018 \\
\hline & $\begin{array}{l}\text { IT can enable improved business } \\
\text { processes which might lead to } \\
\text { reduction in corruption }\end{array}$ & $\begin{array}{l}\text { Strategic IS (health information } \\
\text { system) }\end{array}$ & Silva and Hirschheim 2007 \\
\hline & $\begin{array}{l}\text { Digitalization of government } \\
\text { website to reduce corruption }\end{array}$ & $\begin{array}{l}\text { Ministry websites and } \\
\text { egovement portals }\end{array}$ & Goundar 2009 \\
\hline & $\begin{array}{l}\text { ICT helped corruption come to light } \\
\text { thereby leading to its reduction }\end{array}$ & & Lee and Lio 2016 \\
\hline Communication & $\begin{array}{l}\text { Complaint system might improve } \\
\text { information flow leading to better } \\
\text { service and reduction of corruption }\end{array}$ & $\begin{array}{l}\text { Online Public Grievance } \\
\text { Redressal System }\end{array}$ & Rana et al 2013 \\
\hline $\begin{array}{l}\text { Not clear from } \\
\text { study }(n=40)\end{array}$ & & & $\begin{array}{l}\text { Abu-Shanab et al. 2013, Alryalat at } \\
\text { al 2013, Andersen 2009, Bailard } \\
\text { 2009, Charoensukmongkol and } \\
\text { Moqbel 2014, Choi 2014, Corojan } \\
\text { and Criado 2012, DiRienzo et al. } \\
\text { 2007, Elbahnasawy 2014, Garcia- } \\
\text { Murillo 2013, Hope and Korpoe } \\
\text { 2011, Jha and Sarangi 2017, } \\
\text { Kanyam et al. 2017, Kim 2014, } \\
\text { Kock and Gaskins 2014, Kossow } \\
\text { and Kukutschka 2017, Kovacic } \\
\text { 2005, Krishnan et al. 2013, Lio et al. } \\
\text { 2011, Mimbi and Bankole 2016, } \\
\text { Mistry 2012, Mistry and Jalal 2012, } \\
\text { Nam 2018, Neupane et al. 2012, } \\
\text { Neupane, Soar, and Vaidya 2014, } \\
\text { Oni 2016, Palvia et al 2017, } \\
\text { Priyatman 2008, Raghupathi and } \\
\text { Wu 2011, Sassi and Ben Ali 2017, } \\
\text { Saxena 2017, Shim and Eom 2008, } \\
\text { Shim and Eom 2009, Soper 2007, } \\
\text { Srivastava et al 2007, Srivastava et } \\
\text { al. 2016, Valle-Cruz et al. 2016, } \\
\text { Walle at al 2018, Zhao and Xu } \\
\text { 2015, Zhao et al. 2017 }\end{array}$ \\
\hline
\end{tabular}

Table 4: Expectations of digital technology effects on corruption in developing countries

In general, digitalization is expected to enable improvements in business processes, enable 
transparency and monitoring, as well as deter corrupt behaviours $(\mathrm{n}=29)$. Depending on the type of digital technologies - information, computing, communication, and connectivity technologies (Bharadwaj, El Sawy, Pavlou, \& Venkatraman, 2013; Vial, 2019: 121)—other specific expectations might be derived in relation to government corruption. Digital technologies are deployed in the government administrations of developing countries with direct or indirect expectations of effects on corruption. Relatively few studies consider digitalization as an explicit tool for anti-corruption (Table 4). For such studies, expectations of digital technologies might be directly informed by the expectations of an anticorruption strategy, and its hypothesis of the causes and materialization of a given corruption instance (Kim et al., 2009; Saddler, 2007; Syed \& Bandara, 2019; Veeraraghavan, 2013).

Informed by research in the sociotechnical tradition, we reviewed the literature with an eye toward assessing the various ways digital technologies are sociotechnically implicated with corruption within government administration contexts and broader socioeconomic contexts of developing countries. Specifically, our coding of the literature was influenced by information systems research on developing countries that has drawn attention to the significance of context generally, and the salience of the developing country context in shaping focal technology phenomena (Avgerou, 2017; Avgerou \& Madon, 2004). This approach is justified because of its potential to shed light on puzzles presented in the literature such as (1) whether and how digitalization's implications for government corruption in developing countries differs from those elsewhere or digitalization more generally (2) why corruption appears endemic in developing countries and how such endemic corruption interplays with digitalization (3) why digitalization has been suggested to perform below expectation in the fight against government corruption in developing countries. 


\subsection{Toward a Framework of Digitalization and Government Corruption in Developing}

\section{Countries}

Our inductive framework (Figure 2) and subsequent sections synthesize extant knowledge on digitalization and government corruption in developing countries.

Broader socioeconomic context of developing countries

- Political systems

Level of Infrastructural development

Level of socioeconomic development

Regulatory environment/ rule of law etc., 9. (Re)shapes

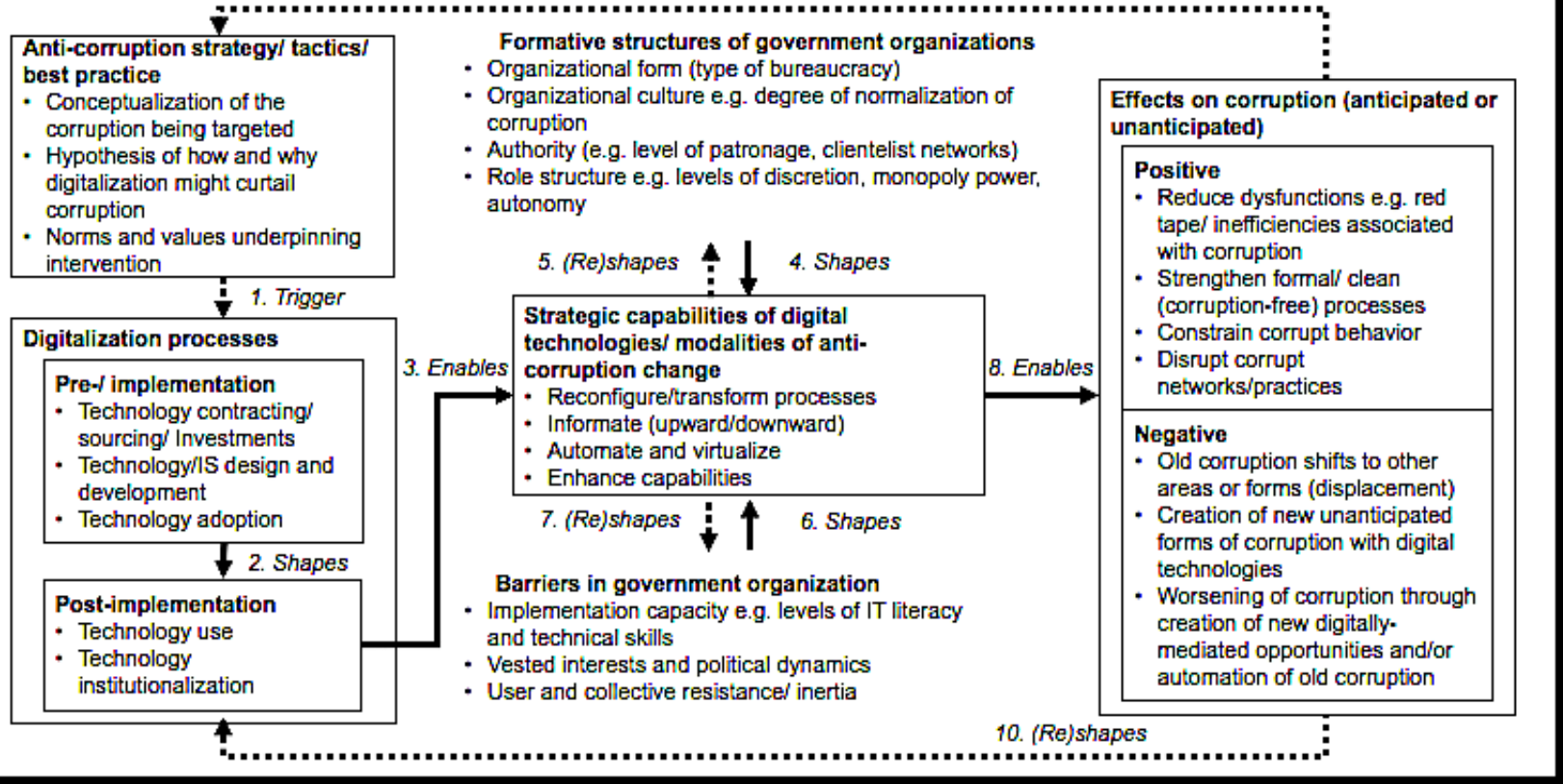

Figure 2: Key issues identified from literature on digitalization and government corruption in developing countries. Arrows only indicate suggested sequences and links in the literature rather than established causal or statistical associations. Solid arrows represent issues reported in the literature and dotted arrows represent underexplored or unexplored issues.

Figure 2 summarizes issues and linkages that emerged from our analysis and suggests that within the broader context of developing countries, anti-corruption strategies, 'best practices' or tactics may trigger a set of digitalization processes that might enable the strategic benefits of digital technologies to be realized as modalities of anti-corruption change in specific government administration settings under a set of formative structures and barriers that influence positive or negative outcomes with respect to corruption.

The Phenomena (content) of digitalization and corruption 
Given the significance of context in sociotechnical change (Avgerou, 2001, 2019), we conceptually distinguish from the literature the focal phenomena of digitalization and corruption (the content of change) from its organizational (Ein-Dor \& Segev, 1982) and broader context (Hayes \& Westrup, 2012; Njihia \& Merali, 2013). We identified the content of digitalization as involving strategic, best practice, or tactical motivations that trigger technology investments, design and development, sourcing and adoption of digital technologies to be used and institutionalized with a view to enacting strategic benefits of digital technologies to create modalities of anti-corruption change that might enable effects on the levels or types of corruption. Each of these constituent elements in the literature are explicated in turn and their connections assessed.

\section{Anti-corruption strategy}

Despite an established view that structure and processes follow strategy (Chandler, 1962), not all organizational reforms involving digital technologies in developing countries are strategic. While some technology implementations might be guided by an organizational or national strategy, others might be 'me too' (copycat) implementations, tactical (ad hoc), or aspiring to some set of 'best practices', no matter how ill-fitting (Andrews, 2012).

In the literature on controlling corruption there are two notable countries, Hong Kong and Singapore, that have managed to stamp out corruption within a relatively short period of time (Klitgaard, 1991). In the case of Singapore, often cited as a poster child of anti-corruption, the reform efforts, often linked to digitalization, were based on an explicit national anticorruption strategy that was aligned with the country's socioeconomic development plans (Hanna \& Knight, 2012; Hin, 2007; Lim Kah Hwee, 2016; Yang \& Wang, 2013). Singapore’s anti-corruption strategy framed corruption primarily as an issue of legal and ethical violation and envisaged digitalization as playing a role in strengthening monitoring, compliance, and law enforcement to improve trust and confidence in public organizations (Quah, 2001). 
The use of digital technologies was also part of an overall strategic vision to digitalize all government agencies and to transform the public sector (Ha, 2013; Hin \& Subramaniam, 2005). Singapore's case illustrates the importance of having (1) an underpinning anticorruption strategy to guide the development and deployment of digital technologies (2) a holistic national anti-corruption strategy that integrates digitalization as part of broader public sector reforms and (3) the establishment of an independent anti-corruption watchdog organization with strong investigative and enforcement powers to work alongside administrative reform efforts (Klitgaard, 1991).

For example, in the areas of international trade and customs clearance, Singapore's development and deployment of the TRADENET platform - an EDI system to integrate multiple stakeholders and to streamline processes - was aligned with the country's strategy to become a world-leading port nation with high efficiency and low corruption to overcome its natural disadvantage of small size while leveraging its ideal geographic location for shipping (King \& Konsynski, 1995; Teo, Tan, \& Wei, 1997). Just a few years after TRADNET implementation Singapore became a remarkable success story not only for its world-leading port sector but also as the least corrupt nation in Asia and one of the least corrupt in the world that is noted for the integrity of its public servants (Civil Service College (Singapore), 2015). Digitalization was carried out alongside wholesale reforms and strict law enforcement that ensured the routine jailing of corrupt government officials and individuals (Singapore Customs and Corrupt Practices Investigation Bureau, 2018).

Other developing countries such as Ghana and Mauritius that subsequently adopted Singapore's TRADENET as a best practice (De Wulf, 2005) have not had underpinning anticorruption strategies as ambitious or encompassing as Singapore's. In Ghana's case, TRADENET was implemented within a remit of improving efficiencies in trade clearance but despite the potential of the technology, corruption continued to persist and co-exist alongside 
other improvements within customs and the ports (Addo, 2016; Addo \& Senyo, 2020). Table

5 summarizes motivations underpinning digitalization and corruption in the literature.

\begin{tabular}{|l|l|l|}
\hline $\begin{array}{l}\text { Is digitalization } \\
\text { strategic? }\end{array}$ & $\begin{array}{l}\text { Nature of } \\
\text { digitalization and } \\
\text { anticorruption } \\
\text { approach }\end{array}$ & Study \\
\hline Yes (n=23) & Strategic (n=18) & $\begin{array}{l}\text { Bhuiyan 2011, Cho and Choi 2004, Davis 2004, Goundar 2009, } \\
\text { Heeks 1998, Kim et al. 2009, Martinez 2015, Masiero 2015, } \\
\text { Nugroho 2014, Owusu-Oware et al 2018, Ramasoota 1998, Silal et } \\
\text { al 2019, Silva and Hirschheim 2007, Stamati et al. 2015, Syed et al } \\
\text { 2019, Twinomurinzi et al 2011, Veeraraghavan 2013, Xinli 2015 }\end{array}$ \\
\cline { 2 - 3 } & Best practice (n=5) & $\begin{array}{l}\text { Addo 2016, Addo 2018, Amankwah-Safo et al 2018, Kock and } \\
\text { Gaskins 2013, Senyo et al 2019 }\end{array}$ \\
\hline No & Tactical & Choudrie et al. 2017, Stremlau et al. 2015 \\
\hline Not clear from study (n=23) & $\begin{array}{l}\text { Ameen and Ahmad 2013, Bellini 2014, Berman and Tettey 2001, } \\
\text { Corojan and Criado 2012, Introna et al. 2010, Kock and Gaskins } \\
\text { 2014, Lee and Lio 2016, Mahmood 2004, Neupane, Soar, and } \\
\text { Vaidya 2015, Oni 2016, Palvia et al 2017, Pankowska 2017, } \\
\text { Pathak et al. 2009, Peterson 1998, Prasad and Shivarajan 2015, } \\
\text { Priyatman 2008, Rana et al 2013 } \\
\text { Rana et al 2014, Sahay and Puri 2008, Selke et al. 2008, Seo and } \\
\text { Warman 2011, Therese and Azwe 2016, Vaidya and Myers 2017 }\end{array}$ \\
\hline
\end{tabular}

Table 5: Association of digitalization with anti-corruption strategies in developing countries

A bulk of the literature $(n=23)$ does not indicate the linkage of digitalization to an anticorruption strategy. Others suggest motivations and goals that are not uniquely strategic for the organization or context, but might copy 'best practice' (Addo, 2016; Amankwah-sarfo, Boateng, \& Effah, 2018; Kock \& Gaskins, 2013; Senyo, Liu, \& Effah, 2019b), or be tactical i.e., have short-term expectations derived from a general belief in the potential of digital technologies to transform organization (Stremlau, Fantini, \& Gagliardone, 2015).

Overall, this remains an important area for further research as a number of pertinent questions remain unexplored in the literature. For example, it remains unclear (1) how anticorruption strategies are formulated and implemented in developing countries and by whom. Understanding this might provide insights into the power dynamics, values and influences that animate anti-corruption efforts in such contexts (2) how various anticorruption strategies come to be linked with digitalization to trigger specific processes (rather than others). The role of consultants and technology vendors needs to be better understood (Veeraraghavan, 2013), as does the role of political actors and decision-makers because there is evidence that deployment of technology can be a highly political rather than objective process, and linked to vast corruptible networks (Sahay, 2008) (3) the degree of dynamism of such strategies and how 
they adapt to feedback from the environment and particularly from ongoing digitalization effects on corruption. For example, the IS strategy literature has distinguished between strategy and 'strategizing' (Besson \& Rowe, 2012; Levy, Powell, \& Galliers, 1999), with the later emphasising the dynamism of strategic play i.e., strategy-as-practice and aligning-inpractice - what "managers and other organizational actors do in their day-to-day activities to achieve alignment" (Karpovsky \& Galliers, 2015: 137).

\section{Digitalization processes}

Given its endemic nature in developing countries, it should come as no surprise that all stages of digitalization from pre-implementation to post-implementation are associated with government corruption. Technology investments have been associated with mixed results on corruption (Charoensukmongkol \& Moqbel, 2014), and government digitalization projects, like other public sector projects in developing countries are prone to corruption (Damoah, Akwei, Amoako, \& Botchie, 2018). Table 6 summarizes corruption related issues associated with various stages of digital technology deployment and use.

\begin{tabular}{|c|c|c|}
\hline Stage of digitalization & Aspect of process & Study \\
\hline \multirow{2}{*}{$\begin{array}{l}\text { Post-implementation } \\
(\mathrm{n}=18)\end{array}$} & Institutionalization & Addo 2016 \\
\hline & Use $(n=17)$ & $\begin{array}{l}\text { Addo 2018, Amankwah-Safo et al 2018, Davis } \\
\text { 2004, Heeks 1998, Kock and Gaskins 2013, } \\
\text { Martinez 2015, Nugroho 2014, Owusu-Oware et } \\
\text { al 2018, Ramasoota } 1998 \text {, Senyo et al } 2019 \text {, } \\
\text { Silal et al 2019, Stamati et al. 2015, Stremlau et } \\
\text { al. 2015, Syed et al 2019, Twinomurinzi et al } \\
\text { 2011, Veeraraghavan 2013, Xinli } 2015\end{array}$ \\
\hline \multirow[t]{3}{*}{$\begin{array}{l}\text { Pre-Implementation } \\
(\mathrm{n}=7)\end{array}$} & Institutionalization $(n=4)$ & $\begin{array}{l}\text { Bhuiyan 2011, Choudrie et al. 2017, Kim et al. } \\
\text { 2009, Silva and Hirschheim } 2007\end{array}$ \\
\hline & $\begin{array}{l}\text { Technology/IS design and } \\
\text { development }\end{array}$ & Goundar 2009 \\
\hline & Use & Cho and Choi 2004, Masiero 2015 \\
\hline \multicolumn{2}{|c|}{ Not clear from study $(n=23)$} & $\begin{array}{l}\text { Ameen and Ahmad 2013, Bellini 2014, Berman } \\
\text { and Tettey 2001, Corojan and Criado 2012, } \\
\text { Introna et al. 2010, Kock and Gaskins 2014, Lee } \\
\text { and Lio 2016, Mahmood 2004, Neupane, Soar, } \\
\text { and Vaidya 2015, Oni 2016, Palvia et al 2017, } \\
\text { Pankowska 2017, Pathak et al. 2009, Peterson } \\
\text { 1998, Prasad and Shivarajan 2015, Priyatman } \\
\text { 2008, Rana et al 2013, Rana et al 2014, Sahay } \\
\text { and Puri 2008, Selke et al. 2008, Seo and } \\
\text { Warman 2011, Therese and Azwe 2016, Vaidya } \\
\text { and Myers 2017 }\end{array}$ \\
\hline
\end{tabular}

Table 6: Corruption related issues at various stages of digitalization 
Digitalization and its technologies are institutional and involve actors and stakeholders with diverse interests acting across domains from the local to the global (Avgerou, 2003). Actors involved might span the public-private spheres, for example, technology consultants, vendors and entrepreneurs might engage in public-private partnerships with government actors (Hartnett, Daniel, \& Holti, 2012; Saint-Martin, 2000). In the pre-implementation stage, vast sums of typically donor money are invested in sourcing, purchasing and contracting and this creates susceptibility to the kinds of corruption associated with public project spending in developing countries such as bribery for contracts, kickbacks, self-dealing, cronyism or even the theft of project funds (Locatelli, Mariani, Sainati, \& Greco, 2017).

During the design, development and adoption of anti-corruption systems, vested interests keen on preserving the status quo might limit the potential of technology by pushing for sub-optimal system configurations that may be less threatening to established corrupt practices (Addo, 2017), or by sabotaging digitalization in other ways (Veeraraghavan, 2013: 249). Digital systems that come to be used in government have therefore typically been preshaped by corruption and vested interested with such influences conditioning the nature and extent of use, as well as the possibility, nature and extent for institutionalization into existing practices. Corruption has also been associated with the use and institutionalization of digital artefacts during both implementation and post-implementation. For example, processes for vendor, partner and consultant selection during digitalisation projects might be associated with politicization, real or perceived corruption, and powerful officials might chose to end digitalization initiatives at whim once there is change in political power or leadership (Sahay, 2008; Silva \& Hirschheim, 2007).

\section{Strategic capabilities of digital technologies and modalities of anti-corruption change}

Digital technologies or their uses do not necessarily cause anti-corruption effects. The IS literature has distinguished between objective technology (material artefacts and systems) and 
enacted technology (systems under subjective use in particular social and organizational contexts)(Cordella \& Iannacci, 2010; Fountain, 2001). Under certain formative conditions, digital technologies might enable the strategic capabilities of information and digital technologies to be realized as modalities for anti-corruption change.

Strategic capabilities of digital technologies identified in the IS literature include automation (replacing human labour in processes), informating (providing more and better information about organizational activities upward toward management and downward toward employees and users), and transformation (fundamentally redefining processes and relationships) (Dehning, Richardson, \& Zmud, 2003). Digital technologies have also been used to strategically enhance or enable organizational capabilities. Table 7 summarizes the strategic capabilities of digital technologies in relation to the modalities of anti-corruption change they have been associated with in the literature.

\begin{tabular}{|c|c|c|}
\hline $\begin{array}{l}\text { Strategic role of digital } \\
\text { technologies (Types) }\end{array}$ & Implication in practice & Study \\
\hline \multirow[t]{7}{*}{$\begin{array}{l}\text { Reconfigure/ Transformation } \\
\text { processes }(n=9)\end{array}$} & $\begin{array}{l}\text { Digitalization was undertaken to improve business } \\
\text { processes (Customs and port processes) and reduce } \\
\text { corruption }\end{array}$ & $\begin{array}{l}\text { Addo 2018, Amankwah-Safo et al 2018, } \\
\text { Senyo et al } 2019\end{array}$ \\
\hline & $\begin{array}{l}\text { Reduce corrupt practices associated with NHIA such } \\
\text { as multiple identifies, fake IDs, fraudulent billing, ghost } \\
\text { patients and impersonation }\end{array}$ & Owusu-Oware et al 2018 \\
\hline & Curbed workaround processes that enable corruption & Syed et al 2019 \\
\hline & $\begin{array}{l}\text { ERP implementation meant to improve processes to } \\
\text { increase efficiency and reduce corruption }\end{array}$ & Choudrie et al. 2017 \\
\hline & $\begin{array}{l}\text { Part of broader strategy to improve hospital } \\
\text { management and help in the fight against corruption } \\
\text { in Guatemala's two largest hospitals }\end{array}$ & Silva and Hirschheim 2007 \\
\hline & $\begin{array}{l}\text { Computerization was purposefully aimed to fight } \\
\text { leakage ("rice mafia") in the PDS }\end{array}$ & Masiero 2015 \\
\hline & $\begin{array}{l}\text { TradeNet intended to streamline processes to reduce } \\
\text { inefficiencies and lack of transparency and monitoring } \\
\text { that leads to corruption }\end{array}$ & Addo 2016 \\
\hline \multirow[t]{6}{*}{ Informate downward $(\mathrm{n}=7)$} & $\begin{array}{l}\text { Government ministries embarked on digital } \\
\text { transformation of Fiji to ensure transparency }\end{array}$ & Goundar 2009 \\
\hline & $\begin{array}{l}\text { Various Greek government initiatives make } \\
\text { government more transparent to citizens }\end{array}$ & Stamati et al. 2015 \\
\hline & $\begin{array}{l}\text { Radio might enable citizens gain information about } \\
\text { government; call-in programs might allow citizens to } \\
\text { hold office holders to account }\end{array}$ & Stremlau et al. 2015 \\
\hline & $\begin{array}{l}\text { OPEN allows disclosure and tracking of citizen } \\
\text { requests thereby enabling transparency }\end{array}$ & Cho and Choi 2004, Kim et al. 2009 \\
\hline & $\begin{array}{l}\text { E-procurement system allows more visibility for all } \\
\text { transacting parties }\end{array}$ & Nugroho 2014 \\
\hline & $\begin{array}{l}\text { System provides accessible information to various } \\
\text { stakeholders to enable transparency in procurements }\end{array}$ & Martinez 2015 \\
\hline \multirow[t]{3}{*}{ Informate upward $(n=4)$} & $\begin{array}{l}\text { The Electronic Monitoring System (EMS) helps } \\
\text { monitor activities }\end{array}$ & Xinli 2015 \\
\hline & Population surveillance and civil registration services & Ramasoota 1998, Veeraraghavan 2013 \\
\hline & $\begin{array}{l}\text { Various systems meant to enhance transparency and } \\
\text { management controls }\end{array}$ & Davis 2004 \\
\hline Enhance capabilities $(n=4)$ & $\begin{array}{l}\text { Internet enables citizens to have voice and demand } \\
\text { accountability to fight government corruption }\end{array}$ & Kock and Gaskins 2013 \\
\hline
\end{tabular}




\begin{tabular}{|l|l|l|}
\hline & $\begin{array}{l}\text { To enable citizen mobilization online to unseat the } \\
\text { powerful groups }\end{array}$ & Twinomurinzi et al 2011 \\
\cline { 2 - 3 } & Technology to render capabilities for 'panoptic' control & Heeks 1998 \\
\cline { 2 - 3 } & $\begin{array}{l}\text { As part of broader e-government initiatives to } \\
\text { modernize government }\end{array}$ & Bhuiyan 2011 \\
\hline Automate/virtualize & $\begin{array}{l}\text { To enable citizen use e-government services as } \\
\text { anticorruption tools }\end{array}$ & Silal et al 2019 \\
\hline Not clear from study ( $\mathrm{n}=23)$ & $\begin{array}{l}\text { Ameen and Ahmad 2013, Bellini 2014, } \\
\text { Berman and Tettey 2001, Corojan and } \\
\text { Criado 2012, Introna et al. 2010, Kock } \\
\text { and Gaskins 2014, Lee and Lio 2016, } \\
\text { Mahmood 2004, Neupane, Soar, and } \\
\text { Vaidya 2015, Oni 2016, Palvia et al } \\
\text { 2017, Pankowska 2017, Pathak et al. } \\
\text { 2009, Peterson 1998, Prasad and } \\
\text { Shivarajan 2015, Priyatman 2008, Rana } \\
\text { et al 2013, Rana et al 2014, Sahay and } \\
\text { Puri 2008, Selke et al. 2008, Seo and } \\
\text { Warman 2011, Therese and Azwe 2016, } \\
\text { Vaidya and Myers 2017 }\end{array}$ \\
\hline
\end{tabular}

Table 7: Strategic capabilities of digital technologies as modalities of anti-corruption change

When digital technologies are strategically deployed for reconfiguration and transformation, the essence is to improve business processes to curb the use of unofficial channels, reduce corrupt practices, and fight leakage of revenues or public goods (Addo, 2018; Amankwah-sarfo et al., 2018; Choudrie, Zamani, Umeoji, \& Emmanuel, 2017; Senyo et al., 2019b). Where digital technologies were strategically used to informate downward, the essence was to provide more information to citizens in an effort to deepen transparency and to curb shoddy practices that thrive on opaque processes (Goundar, 2009; Kim \& Cho, 2005; Stamati, Papadopoulos, \& Anagnostopoulos, 2015). On the other hand, where digital technologies are strategically deployed to informate upwards, the motivation was to empower stakeholders to monitor and scrutinize actors in positions of power (Davis, 2004; Ramasoota, 1998; Veeraraghavan, 2013). To enhance capabilities, digital technologies were used in unconventional ways to fight corruption through online mobilisation and protests as well as demand for accountability (Kock \& Gaskins, 2013; Twinomurinzi, 2011). Lastly, digital technologies were strategically used for automation to curb corruption associated with physical or human-mediated processes (Silal, Jha, \& Saha, 2019). Given that majority of extant literature have not considered the strategic use of digital technologies for fighting government corruption, a fertile opportunity is presented for future research to systematically explore. 
We assess how the organizational settings of government administration and the broader context of developing countries shape the enactment of various modalities of anti-corruption enabled by the strategic capabilities of digital technologies. Such consideration of context is key to unravelling the puzzles identified in section 3.2 (1) whether and how digitalization's implications for government corruption in developing countries differs from those elsewhere or digitalization more generally (2) why corruption appears endemic in developing countries and how such endemic corruption interplays with digitalization (3) why digitalization has been suggested to perform below expectation in the fight against government corruption.

\section{Broader socioeconomic context of developing countries}

Cross-national studies have associated corruption with lower levels of socioeconomic development although the direction of causality remains debatable (Bardhan, 1997; Olken \& Pande, 2012). Table 8 presents various aspects of the broader socioeconomic context of developing countries and their manifestations in shaping corruption and digitalization.

\begin{tabular}{|c|c|c|}
\hline $\begin{array}{l}\text { Aspect of } \\
\text { broader } \\
\text { national } \\
\text { context }\end{array}$ & Salience/manifestation & Study \\
\hline \multirow{13}{*}{$\begin{array}{l}\text { Socioeconomic } \\
\text { development } \\
(n=15)\end{array}$} & $\begin{array}{l}\text { Physical interactions in the port coupled with shadow networks enabled } \\
\text { corruption }\end{array}$ & $\begin{array}{l}\text { Amankwah-Safo et al 2018, Senyo et } \\
\text { al } 2019\end{array}$ \\
\hline & General acceptability of corruption across society and public organization & Heeks 1998 \\
\hline & $\begin{array}{l}\text { Parasitic relationships in processes that foster corruption, Income and } \\
\text { livelihood }\end{array}$ & Syed et al 2019, Veeraraghavan 2013 \\
\hline & Endemic corruption across society & Davis 2004 \\
\hline & $\begin{array}{l}\text { IT failed to stamp out corruption as behavioral and socioeconomic } \\
\text { conditions are not adequately considered }\end{array}$ & Addo 2018 \\
\hline & Neopatrimonial context of country shaped TradeNet anti-corruption efforts & Addo 2016 \\
\hline & Social influence enabled adoption and continued use of system & Nugroho 2014 \\
\hline & Previously, there was more physical interaction and limited information & Goundar 2009 \\
\hline & $\begin{array}{l}\text { State effort for efficient surveillance of population and civil registrations to } \\
\text { reduce fraud and corruption }\end{array}$ & Ramasoota 1998 \\
\hline & $\begin{array}{l}\text { There is high level of greed associated with power minority groups, leading } \\
\text { to corruption }\end{array}$ & Twinomurinzi et al 2011 \\
\hline & $\begin{array}{l}\text { Supervision departments of local governments and anti-corruption agencies } \\
\text { collaboration was critical }\end{array}$ & Xinli 2015 \\
\hline & $\begin{array}{l}\text { Social and cultural factors such as gender, poverty, level of education, } \\
\text { class, caste, age, and social exclusion can all directly impede the use of } \\
\text { computers in developing dialogue with government using ICTs }\end{array}$ & Bhuiyan 2011 \\
\hline & $\begin{array}{l}\text { Misclassification of poverty line changed dynamics of demand and supply } \\
\text { that pushed ration shops to divert to private market to stay afloat }\end{array}$ & Masiero 2015 \\
\hline \multirow{5}{*}{$\begin{array}{l}\text { Political } \\
\text { systems }(n=7)\end{array}$} & Agent of change turn to become agent of exploitation and corruption & Vaidya and Myers 2017 \\
\hline & $\begin{array}{l}\text { Implementation of SIS was halted after elections brought in new political } \\
\text { regime; reforms staff and SIS staff all fired }\end{array}$ & Silva and Hirschheim 2007 \\
\hline & $\begin{array}{l}\text { Strong political leadership at state level enabled implementation in spite of } \\
\text { weaker federal support }\end{array}$ & Choudrie et al. 2017 \\
\hline & Network of actors within ICT4D project chain are responsible for corruption & Sahay and Puri 2008 \\
\hline & Agency and ministerial structure linked to broader political regime & Martinez 2015 \\
\hline
\end{tabular}




\begin{tabular}{|c|c|c|}
\hline & $\begin{array}{l}\text { Rigid legalism as the underlying principle for accountability with clientelism } \\
\text { as the rationale for selecting policies and objectives }\end{array}$ & Stamati et al. 2015 \\
\hline & $\begin{array}{l}\text { Patronage politics shapes radio programs and conditions their potential to } \\
\text { enable accountability }\end{array}$ & Stremlau et al. 2015 \\
\hline \multirow{3}{*}{$\begin{array}{l}\text { Infrastructural } \\
\text { development } \\
(n=3)\end{array}$} & $\begin{array}{l}\text { Citizen's did not previously make their voices heard for accountability, hence } \\
\text { the persist of corruption }\end{array}$ & Kock and Gaskins 2013 \\
\hline & $\begin{array}{l}\text { Unavailability of an integrated socio-technical approach to fight corruption in } \\
\text { the health sector }\end{array}$ & Owusu-Oware et al 2018 \\
\hline & $\begin{array}{l}\text { Corruption occurs due to limited computer efficacy of citizen and e- } \\
\text { readiness for e-government participation }\end{array}$ & Silal et al 2019 \\
\hline $\begin{array}{l}\text { Regulatory } \\
\text { environment/ } \\
\text { rule of law }\end{array}$ & OPEN was backed by strong regulation and enforcement & Cho and Choi 2004, Kim et al. 2009 \\
\hline \multicolumn{2}{|c|}{ Not clear from study $(n=21)$} & $\begin{array}{l}\text { Ameen and Ahmad 2013, Bellini 2014, } \\
\text { Berman and Tettey 2001, Corojan and } \\
\text { Criado 2012, Introna et al. 2010, Kock } \\
\text { and Gaskins 2014, Lee and Lio 2016, } \\
\text { Mahmood 2004, Neupane, Soar, and } \\
\text { Vaidya 2015, Oni 2016, Palvia et al } \\
\text { 2017, Pankowska 2017, Pathak et al. } \\
\text { 2009, Peterson 1998, Prasad and } \\
\text { Shivarajan 2015, Priyatman 2008, } \\
\text { Rana et al 2013, Rana et al 2014, } \\
\text { Selke et al. 2008, Seo and Warman } \\
\text { 2011, Therese and Azwe } 2016\end{array}$ \\
\hline
\end{tabular}

Table 8: Broader national context and its salience for corruption and digitalization

Corruption in developing countries persist due to socioeconomic issues such as lowincome levels and distinctive political economy (Robinson, 1998), as well as cultural issues such as neopatrimonialism and strong informal ties (Addo \& Senyo, 2020; Hopper, 2017). When corruption becomes endemic, select groups of powerful people benefit by using their influence to tame or capture the political system (Awofeso \& Odeyemi, 2014). Given that people responsible for fixing the political system are embedded in corrupt networks, agents of change become agents of corruption (Sahay, 2008; Vaidya, Myers, \& Myers, 2017).

Corruption also thrives in developing countries due to the absence of infrastructural development such as internet penetration (Kock \& Gaskins, 2013). In some developing countries, access to digital infrastructure such as reliable internet and digital platforms is a challenge (Bhuiyan, 2011; Owusu-oware \& Boateng, 2018). This is worsened by low digital literacy and computer skills of citizens (Silal et al., 2019), all of which make citizens unable to fully utilise digital technologies for anti-corruption.

\section{Formative structures of government administration}

Digitalization processes in organizations are not acontextual but rather occur under formative conditions that imbue them with meaning, legitimacy, and endurance (Ciborra \& Lanzara, 
1994). In the government administrations of developing countries, particular structures have

been identified as shaping the enactment of strategic capabilities of digital technologies and

modalities for anti-corruption. Table 9 presents examples from the literature.

\begin{tabular}{|c|c|c|}
\hline $\begin{array}{l}\text { Structures in } \\
\text { formative } \\
\text { context }\end{array}$ & Salience/ manifestations & Study \\
\hline \multirow{10}{*}{$\begin{array}{l}\text { Nature of } \\
\text { bureaucracy } \\
(n=14)\end{array}$} & Bureaucracy is politicized and influenced by powerful politicians & Martinez 2015, Vaidya and Myers 2017 \\
\hline & Strongly coupled relationships between corrupt actors & Owusu-Oware et al 2018 \\
\hline & Strong support of manual interactions & Goundar 2009 \\
\hline & Unavailability of clear channels to demand accountability & Kock and Gaskins 2013 \\
\hline & Limited openness and accountability & Stamati et al. 2015, Veeraraghavan 2013 \\
\hline & $\begin{array}{l}\text { Normalized corruption and patronage in the government sphere } \\
\text { intertwined with societal }\end{array}$ & Davis 2004 \\
\hline & $\begin{array}{l}\text { Strong administration capacity and existing infrastructures } \\
\text { enabled success }\end{array}$ & Cho and Choi 2004, Kim et al. 2009, Xinli 2015 \\
\hline & $\begin{array}{l}\text { Statutes that regulate organizational arrangement of Ministry } \\
\text { was obstacle to SIS }\end{array}$ & Silva and Hirschheim 2007 \\
\hline & $\begin{array}{l}\text { Facilitating conditions and top management support enabled } \\
\text { adoption and use }\end{array}$ & Nugroho 2014 \\
\hline & $\begin{array}{l}\text { Decentralized district level administration enabled } \\
\text { implementation }\end{array}$ & Ramasoota 1998 \\
\hline \multirow{8}{*}{$\begin{array}{l}\text { Organizational } \\
\text { culture } \\
\text { (degree of } \\
\text { normalization } \\
\text { of corruption) } \\
(\mathrm{n}=9)\end{array}$} & Agents internalize bureaucratic culture and practices & Heeks 1998 \\
\hline & $\begin{array}{l}\text { Corruption has been normalized in the implementation of ICT4D } \\
\text { project, so actors are willing to deal with people who will reason } \\
\text { with them in the implementation of projects }\end{array}$ & Sahay and Puri 2008 \\
\hline & Formation of patrimonial and bureaucratic networks & Addo 2018 \\
\hline & $\begin{array}{l}\text { Mild punishment and sometime no action were taken against } \\
\text { corruption actors }\end{array}$ & Amankwah-Safo et al 2018, Senyo et al 2019 \\
\hline & Parasitic structure of corruption & Syed et al 2019 \\
\hline & $\begin{array}{l}\text { Normalized corruption and patronage in the government sphere } \\
\text { intertwined with societal }\end{array}$ & Stremlau et al. 2015 \\
\hline & $\begin{array}{l}\text { Flattening hierarchies and decentralizing access to information } \\
\text { on to the desks of all employees and in promoting associated } \\
\text { changes in power within organizations, are seen as a direct } \\
\text { threat to many senior staff, who then block adoption }\end{array}$ & Bhuiyan 2011 \\
\hline & $\begin{array}{l}\text { Culture has a strong impact within the context of developing } \\
\text { countries, too. Older individuals and those who travelled abroad } \\
\text { were respected more than others. While aspects pertaining to } \\
\text { the working conditions are often disregarded by studies } \\
\text { conducted in developed countries (e.g., existence of equipment, } \\
\text { infrastructure) [...] for developing countries may be important } \\
\text { factors, governing and affecting the working practices }\end{array}$ & Choudrie et al. 2017 \\
\hline \multirow[t]{3}{*}{$\begin{array}{l}\text { Role structure } \\
(n=3)\end{array}$} & $\begin{array}{l}\text { Citizens are not empowered to use e-government services as } \\
\text { anticorruption tools }\end{array}$ & Silal et al 2019 \\
\hline & $\begin{array}{l}\text { Customs officers have excessive discretion and monopoly and } \\
\text { low accountability }\end{array}$ & Addo 2016 \\
\hline & $\begin{array}{l}\text { Role of ration dealership exposes them to risks that can only be } \\
\text { minimized by leaking to the free market }\end{array}$ & Masiero 2015 \\
\hline Authority & $\begin{array}{l}\text { Powerful individuals have access to government power as result } \\
\text { of position they occupy }\end{array}$ & Twinomurinzi et al 2011 \\
\hline \multicolumn{2}{|c|}{ Not clear from study $(n=21)$} & $\begin{array}{l}\text { Ameen and Ahmad 2013, Bellini 2014, Berman } \\
\text { and Tettey 2001, Corojan and Criado 2012, } \\
\text { Introna et al. 2010, Kock and Gaskins 2014, Lee } \\
\text { and Lio 2016, Mahmood 2004, Neupane, Soar, } \\
\text { and Vaidya 2015, Oni 2016, Palvia et al 2017, } \\
\text { Pankowska 2017, Pathak et al. 2009, Peterson } \\
\text { 1998, Prasad and Shivarajan 2015, Priyatman } \\
\text { 2008, Rana et al 2013, Rana et al 2014, Selke et } \\
\text { al. 2008, Seo and Warman 2011, Therese and } \\
\text { Azwe 2016 }\end{array}$ \\
\hline
\end{tabular}

Table 9: Salient structures in the formative context of government organizations that shape digitalization and corruption

Instances of formative structures that foster corruption in developing countries include the nature of bureaucracy, organisational culture of normalised corruption, role structure and 
authority. Given that developing countries are characterised by limited digital infrastructure development, government processes are largely manual (paper-based) or semi-digitalised, with high levels of red tape, opaqueness and rigidity (Guriev, 2004; Hull, 2012). Due to the level of frustration associated with bureaucratic processes, citizens are often induced to use unofficial channels to receive swift services, which leads to emergence of corruption in government administrations (Stapenhurst \& Langseth, 1997). In addition, corruption in developing countries is enabled by obsolete laws and unclear regulatory frameworks that work against digitalization and anti-corruption measures (Effah, 2016). For instance, there are laws in some developing countries that deem electronic signatures as null and void. Physical signature is required from government actors who use this opportunity to extort or induce bribes.

Corruption is also enabled and normalized by mild punishment and sometimes no action against corrupt actors (Amankwah-sarfo et al., 2018; Senyo et al., 2019b). Given such impunity, the weak political and justice systems, citizens in developing countries are not empowered to use digital technologies to fight corruption for fear of victimization. Powerful individuals who perpetuate corruption occupy high-level government positions and use the power of their offices to frustrate anti-corruption interventions, victimise and persecute anticorruption campaigners (Twinomurinzi, 2011).

Digitalisation alone is unlikely to change corruption in developing countries if formative structures are not considered holistically. While the extant literature has identified some formative structure manifestations, there is still limited knowledge on how digitalisation can be used strategically to influence these.

\section{Barriers in government organizations}

Aside the enduring organizational structures suggested to shape strategic capabilities of digital technologies and their anti-corruption modalities, barriers within developing country government have also been suggested in the literature. Such barriers are typically attributed to 
individuals or collectives (rather than structures per se) and manifest their salience in myriad

ways. Table 10 summarizes some barriers and their manifestations found from the literature.

\begin{tabular}{|c|c|c|}
\hline Row Labels & Barriers (Manifestations) & Author-date \\
\hline \multirow[t]{10}{*}{$\begin{array}{l}\text { Vested interests/ } \\
\text { organizational } \\
\text { politics }(n=12)\end{array}$} & $\begin{array}{l}\text { Citizens' have not believed in the power of using online } \\
\text { platforms to unseat the powerful groups as well as fear } \\
\text { of victimization }\end{array}$ & Twinomurinzi et al 2011 \\
\hline & $\begin{array}{l}\text { Formation of workaround business processes to } \\
\text { circumvent official processes }\end{array}$ & Syed et al 2019 \\
\hline & $\begin{array}{l}\text { Powerful corrupt actors frustrate anticorruption } \\
\text { measures to protect their interest }\end{array}$ & $\begin{array}{l}\text { Amankwah-Safo et al 2018, Senyo et al 2019, } \\
\text { Veeraraghavan } 2013\end{array}$ \\
\hline & $\begin{array}{l}\text { Presence of bureaucratic culture processes that fuels } \\
\text { vested interests }\end{array}$ & Vaidya and Myers 2017 \\
\hline & $\begin{array}{l}\text { Presence of corruption ensure Custom officers get } \\
\text { additional income and favors }\end{array}$ & Addo 2018 \\
\hline & $\begin{array}{l}\text { Political interests and existing power structures co-opt } \\
\text { openness and accountability mechanisms like radio call- } \\
\text { in programs }\end{array}$ & Stremlau et al. 2015 \\
\hline & $\begin{array}{l}\text { Corruption, as conceptualized in citizens' perception, } \\
\text { does not interest solely the ration dealers, but a system } \\
\text { of actors intertwined with the public and private sectors }\end{array}$ & Masiero 2015 \\
\hline & Various actors subverted technology for their interests & Heeks 1998 \\
\hline & $\begin{array}{l}\text { Issues of ownership and control. Control over access to } \\
\text { information and over its quality and relevance }\end{array}$ & Ramasoota 1998 \\
\hline & $\begin{array}{l}\text { Network of corrupt actors in ICT4D project demand } \\
\text { bribes in the implementation phases of projects }\end{array}$ & Sahay and Puri 2008 \\
\hline \multirow[t]{6}{*}{$\begin{array}{l}\text { User resistance } \\
(n=6)\end{array}$} & $\begin{array}{l}\text { In the beginning, officials in the SMG were reluctant to } \\
\text { use OPEN because of the increased workload. The civil } \\
\text { officials' complaints and concerns also arose from the } \\
\text { reduced possibility of benefiting from corruption }\end{array}$ & Kim et al. 2009 \\
\hline & $\begin{array}{l}\text { Local actors abandoned practices once consultants from } \\
\text { USA had left }\end{array}$ & Choudrie et al. 2017 \\
\hline & $\begin{array}{l}\text { Resistance based on core beliefs of old timers; engineer } \\
\text { was pushed out by line managers who kept blocking } \\
\text { initiatives }\end{array}$ & Silva and Hirschheim 2007 \\
\hline & $\begin{array}{l}\text { Customs officers insisted on using paper declaration } \\
\text { forms despite full digitalization capabilities of TradeNet }\end{array}$ & Addo 2016 \\
\hline & Moral disengagement to justify corruption & Martinez 2015 \\
\hline & Low user resistance as user satisfaction was high & Xinli 2015 \\
\hline \multirow[t]{6}{*}{ Capacity $(n=6)$} & $\begin{array}{l}\text { Citizen's did not have avenues to voice concern and } \\
\text { demand accountability to reduce corruption }\end{array}$ & Kock and Gaskins 2013 \\
\hline & Digital literacy of citizen and limited e-readiness & Silal et al 2019 \\
\hline & $\begin{array}{l}\text { Lack of biometric technology and associated database } \\
\text { integration leads to fraud, impersonation and "ghost" } \\
\text { patient }\end{array}$ & Owusu-Oware et al 2018 \\
\hline & $\begin{array}{l}\text { privacy, security, data management, accessibility, social } \\
\text { inclusion, governance, information policy issues, and } \\
\text { participation }\end{array}$ & Stamati et al. 2015 \\
\hline & $\begin{array}{l}\text { Bangladesh public administration suffers from an acute } \\
\text { shortage of trained personnel, which limits its efficient } \\
\text { operation }\end{array}$ & Bhuiyan 2011 \\
\hline & & Nugroho 2014 \\
\hline Inertia & $\begin{array}{l}\text { People still not comfortable transacting online, } \\
\text { unavailability of technological infrastructure }\end{array}$ & Goundar 2009 \\
\hline $\begin{array}{l}\text { Organized/ } \\
\text { collective } \\
\text { resistance }\end{array}$ & $\begin{array}{l}\text { Various interests collectively act against digitalization } \\
\text { and reforms }\end{array}$ & Davis 2004 \\
\hline \multicolumn{2}{|c|}{ Not clear from study $(n=22)$} & $\begin{array}{l}\text { Ameen and Ahmad 2013, Bellini 2014, Berman } \\
\text { and Tettey 2001, Cho and Choi 2004, Corojan } \\
\text { and Criado 2012, Introna et al. 2010, Kock and } \\
\text { Gaskins 2014, Lee and Lio 2016, Mahmood } \\
\text { 2004, Neupane, Soar, and Vaidya 2015, Oni } \\
\text { 2016, Palvia et al 2017, Pankowska 2017, } \\
\text { Pathak et al. 2009, Peterson 1998, Prasad and } \\
\text { Shivarajan 2015, Priyatman 2008, Rana et al } \\
\text { 2013, Rana et al 2014, Selke et al. 2008, Seo } \\
\text { and Warman 2011, Therese and Azwe } 2016\end{array}$ \\
\hline
\end{tabular}

Table 10: Organizational barriers shaping digitalization and corruption 
Five barriers to anti-corruption are evident in the literature: vested interests, user resistance, capacity, inertia, organized/collective resistance. Vested interest occurs when powerful people influence or take steps protect their source of corruption benefits. Powerful actors sabotage digital technology implementation projects that are considered a threat to their vested interested (Addo, 2016; Amankwah-sarfo et al., 2018; Senyo et al., 2019b; Veeraraghavan, 2013). In cases where digital technologies are deployed to curb corruption, corrupt actors create workaround processes to circumvent official processes (Syed \& Bandara, 2019). In terms of resistance, two forms - user and collective resistances emerged as barriers to ant-corruption digitalisation. User resistance occurs when individuals object to digital technology changes (Addo, 2016) while collective resistance emerges when an organized group such as a department, team or entire organizations object to anti-corruption measures(Davis, 2004; Masiero, 2015). Though some of the resistances are based on issues such as beliefs and dissatisfaction, majority has to do with vested interest to protect a broken system that ensure additional income.

In addition, capacity issues such as limited organizational capabilities and lack of digital skills development are also identified as barriers to anti-corruption digitalisation (Bhuiyan, 2011; Hunnius \& Schuppan, 2013; Owusu-oware \& Boateng, 2018). Lastly, inertia on the part of responsible actors to implement anti-corruption measures. Inertia occurs in the form of deliberate neglect, slow pace or non-trust in digital technologies (Goundar, 2009). As corrupt actors are afraid of the capabilities of digital technology to block corruption loopholes, they are always averse and slow to the use of digital processes. Though few studies have pointed to anti-corruption digitalization barriers, there is still a need for more studies on how barriers manifest and why they persist in developing countries despite digitalization.

Effects of digitalization on government corruption in developing countries 
Given that sociotechnical processes are emergent rather than fully planned/determined, the effects of digitalization on government corruption are not a given. Outcomes might be intended or unintended, and positive or negative. Four possible types of effects on corruption might emerge from the enactment of digitalization in developing country governments: positive intended effects, positive unintended effects, negative intended effects, and negative unintnded effects. Table 11 describes actual negative and positive effects documented in the literature (rather than expectations or assumptions based on the potential of digital technologies).

\begin{tabular}{|c|c|c|c|c|}
\hline Positive effects & Negative Effects & Study & $\begin{array}{l}\text { Inten } \\
\text { ded }\end{array}$ & $\begin{array}{l}\text { Uninten } \\
\text { ded }\end{array}$ \\
\hline & $\begin{array}{l}\text { Efforts to curb corruption with } \\
\text { SIS was marred by political } \\
\text { wrangling and lack of political } \\
\text { will by new administration }\end{array}$ & $\begin{array}{l}\text { Silva and } \\
\text { Hirschhe } \\
\text { im } 2007\end{array}$ & & $x$ \\
\hline & $\begin{array}{l}\text { E-government initiatives that } \\
\text { have been implemented have } \\
\text { little to no effect on increasing } \\
\text { transparency and decreasing } \\
\text { corruption }\end{array}$ & Oni 2016 & & $x$ \\
\hline & $\begin{array}{l}\text { In African bureaucracies, } \\
\text { information systems fail or } \\
\text { underperform more often than } \\
\text { they succeed, because the } \\
\text { saints are few, the demons are } \\
\text { many, the wizards are } \\
\text { inappropriate, the systems are } \\
\text { complex, and the organizations } \\
\text { are weak }\end{array}$ & $\begin{array}{l}\text { Peterson } \\
1998\end{array}$ & & $x$ \\
\hline & $\begin{array}{l}\text { Computers in African states } \\
\text { fails to produce the intended } \\
\text { results (such as corruption } \\
\text { control) because the trajectory } \\
\text { of development of bureaucratic } \\
\text { institutions in Africa has resulted } \\
\text { in internal and external contexts } \\
\text { that differ fundamentally from } \\
\text { those of the Western states } \\
\text { within which computing, and } \\
\text { information technology has } \\
\text { been developed. }\end{array}$ & $\begin{array}{l}\text { Berman } \\
\text { and } \\
\text { Tettey } \\
2001\end{array}$ & & $x$ \\
\hline & $\begin{array}{l}\text { Rather than reforming the } \\
\text { provision of public services, e- } \\
\text { government based } \\
\text { modernization projects are more } \\
\text { likely to reproduce, in more } \\
\text { complex ways, the long- } \\
\text { established public-sector } \\
\text { practices it sought to change. }\end{array}$ & $\begin{array}{l}\text { Introna } \\
\text { et al. } \\
2010\end{array}$ & & $\bar{x}$ \\
\hline & $\begin{array}{l}\text { Agent of change internalise } \\
\text { bureaucratic culture and } \\
\text { practices and become agents of } \\
\text { exploitation and corruption }\end{array}$ & $\begin{array}{l}\text { Vaidya } \\
\text { and } \\
\text { Myers } \\
2017\end{array}$ & & $x$ \\
\hline & $\begin{array}{l}\text { Corruption in ICT4D project is } \\
\text { aided by network of actors } \\
\text { instead of just corrupt } \\
\text { government officials }\end{array}$ & $\begin{array}{l}\text { Sahay } \\
\text { and Puri } \\
2008\end{array}$ & & $x$ \\
\hline & $\begin{array}{l}\text { Local individuals attempted at } \\
\text { first to adhere to the 'western' } \\
\text { ways of working that brought } \\
\text { positive transformations. } \\
\text { However, when the overseas } \\
\text { team members returned to the } \\
\text { USA, the locals fell back to their } \\
\text { old ways and practices [...] } \\
\text { transformations and } \\
\text { improvements were not entirely } \\
\text { adapted and embedded within } \\
\text { the local practices. }\end{array}$ & $\begin{array}{l}\text { Choudrie } \\
\text { et al. } \\
2017\end{array}$ & & $\mathrm{x}$ \\
\hline
\end{tabular}




\begin{tabular}{|c|c|c|c|c|}
\hline & $\begin{array}{l}\text { Technology comes across as } \\
\text { both partial and mistargeted: } \\
\text { partial, because it only targets } \\
\text { the ration dealers and not the } \\
\text { other actors in the supply chain, } \\
\text { and mistargeted, as it } \\
\text { addresses the effect of the } \\
\text { problem and not its root cause. }\end{array}$ & $\begin{array}{l}\text { Masiero } \\
2015\end{array}$ & & $x$ \\
\hline & $\begin{array}{l}\text { Digitalization did not lead to } \\
\text { radical transformation as in } \\
\text { Singapore. Rather, new } \\
\text { practices mixed with old corrupt } \\
\text { ones }\end{array}$ & $\begin{array}{l}\text { Addo } \\
2016\end{array}$ & & $x$ \\
\hline & $\begin{array}{l}\text { Subversion of technology and } \\
\text { controls }\end{array}$ & $\begin{array}{l}\text { Heeks } \\
1998,\end{array}$ & & $x$ \\
\hline & & $\begin{array}{l}\text { Davis } \\
2004\end{array}$ & & $x$ \\
\hline & $\begin{array}{l}\text { Low e-readiness, lack of } \\
\text { infrastructural development, } \\
\text { skills and a digital divide hamper } \\
\text { potential of technology in fight } \\
\text { against corruption }\end{array}$ & $\begin{array}{l}\text { Bhuiyan } \\
2011\end{array}$ & & $x$ \\
\hline & $\begin{array}{l}\text { Radio call-in programmes do } \\
\text { not simply offer a new platform } \\
\text { for citizens to challenge those } \\
\text { who are governing but that they } \\
\text { are also spaces where existing } \\
\text { power structures reproduce } \\
\text { themselves in new forms }\end{array}$ & $\begin{array}{l}\text { Stremlau } \\
\text { et al. } \\
2015\end{array}$ & & $x$ \\
\hline & $\begin{array}{l}\text { System does not fully succeed } \\
\text { in its transparency objectives }\end{array}$ & $\begin{array}{l}\text { Martinez } \\
2015\end{array}$ & & $x$ \\
\hline $\begin{array}{l}\text { Digitalisation removed some avenues for corruption, thereby reduced } \\
\text { corruption }\end{array}$ & & $\begin{array}{l}\text { Senyo et } \\
\text { al } 2019, \\
\text { Amankw } \\
\text { ah-Safo } \\
\text { et al } \\
2018\end{array}$ & $x$ & \\
\hline $\begin{array}{l}\text { Computerization initiatives that reduce uncertainty and asset specificity } \\
\text { of government services lead to lowered perceptions of corruption. }\end{array}$ & & $\begin{array}{l}\text { Prasad } \\
\text { and } \\
\text { Shivaraj } \\
\text { an } 2015\end{array}$ & $x$ & \\
\hline $\begin{array}{l}\text { OPEN system in Korea appears to have had impressive reform and } \\
\text { anti-corruption success through transparency and accountability } \\
\text { mechanisms; and also because of its successful design and } \\
\text { implementation }\end{array}$ & & $\begin{array}{l}\text { Cho and } \\
\text { Choi } \\
2004\end{array}$ & $x$ & \\
\hline $\begin{array}{l}\text { Lowered information asymmetry and corruption through e-government } \\
\text { services }\end{array}$ & & $\begin{array}{l}\text { Silal et al } \\
2019\end{array}$ & $x$ & \\
\hline $\begin{array}{l}\text { When OPEN was introduced in } 1999 \text {, the anti-corruption index of the } \\
\text { SMG was } 64.0 \text {. It increased to } 84.9 \text { in } 2006 \text {, indicating a steady } \\
\text { improvement in transparency }\end{array}$ & & $\begin{array}{l}\text { Kim et } \\
\text { al. } 2009\end{array}$ & $x$ & \\
\hline $\begin{array}{l}\text { Service-delivery oriented IT initiatives contribute to an effective, multi- } \\
\text { pronged strategy to cut corruption in the Fiji public sector. }\end{array}$ & & $\begin{array}{l}\text { Pathak } \\
\text { et al. } \\
2009\end{array}$ & $x$ & \\
\hline $\begin{array}{l}\text { Application of EMS had a positive effect on reducing corruption. IT thus } \\
\text { has the potential to reduce corruption, but the institution and the people } \\
\text { are more important. }\end{array}$ & & $\begin{array}{l}\text { Xinli } \\
2015\end{array}$ & $x$ & \\
\hline $\begin{array}{l}\text { Over the long-term digitalization helped reduce corruption and } \\
\text { improved business processes }\end{array}$ & & $\begin{array}{l}\text { Addo } \\
2018 \\
\end{array}$ & $x$ & \\
\hline $\begin{array}{l}\text { Perceived risk of corruption in manual procurement processes along } \\
\text { with perceived usefulness of e- } \\
\text { Procurement in combating corruption motivated adoption of } \\
\text { the electronic government procurement system. }\end{array}$ & & $\begin{array}{l}\text { Nugroho } \\
2014\end{array}$ & $x$ & \\
\hline $\begin{array}{l}\text { E-procurement technologies have potential to enable corruption control } \\
\text { through several mechanisms }\end{array}$ & & $\begin{array}{l}\text { Neupane } \\
\text {, Soar, } \\
\text { and } \\
\text { Vaidya } \\
2015 \\
\end{array}$ & $x$ & \\
\hline $\begin{array}{l}\text { Digitalization improved population surveillance and civil registration } \\
\text { processes and reduction in corruption such as falsification of ID cards }\end{array}$ & & $\begin{array}{l}\text { Ramaso } \\
\text { ota } 1998 \\
\end{array}$ & $x$ & \\
\hline $\begin{array}{l}\text { ICTs (specifically e-Government) facilitate transparency and } \\
\text { accountability, and limit corruption. Public institutions and their non- } \\
\text { digital procedures also play a significant role in promoting transparent } \\
\text { practices. }\end{array}$ & & $\begin{array}{l}\text { Corojan } \\
\text { and } \\
\text { Criado } \\
2012\end{array}$ & $x$ & \\
\hline $\begin{array}{l}\text { Digitalization helped reduce information asymmetry through online } \\
\text { presence }\end{array}$ & & $\begin{array}{l}\text { Goundar } \\
2009\end{array}$ & $x$ & \\
\hline $\begin{array}{l}\text { ICT had a positive impact on the governance of provincial governments } \\
\text { in China. ICT had two different effects on corruption: ICT helped } \\
\text { corruption cases come to light and ultimately helped reduce corruption }\end{array}$ & & $\begin{array}{l}\text { Lee and } \\
\text { Lio } 2016\end{array}$ & $x$ & \\
\hline $\begin{array}{l}\text { Digitalization helps reduce information asymmetry and provides better } \\
\text { understanding of government processes }\end{array}$ & $\begin{array}{l}\text { The threshold in democratic } \\
\text { developing countries to use ICT } \\
\text { to unseat powerful groups is not } \\
\text { close because citizens do not } \\
\text { believe it is worth the effort to }\end{array}$ & $\begin{array}{l}\text { Twinomu } \\
\text { rinzi et al } \\
2011\end{array}$ & $x$ & $\bar{x}$ \\
\hline
\end{tabular}




\begin{tabular}{|l|l|l|l|l|}
\hline & $\begin{array}{l}\text { fight corruption, and for fear of } \\
\text { victimization }\end{array}$ & & & \\
\hline $\begin{array}{l}\text { Internet offered voice to citizen's to demand for accountability, leading } \\
\text { to corruption reduction }\end{array}$ & & $\begin{array}{l}\text { Kock } \\
\text { and } \\
\text { Gaskins } \\
2013\end{array}$ & $\mathrm{x}$ & \\
\hline $\begin{array}{l}\text { Digitalization helped reduce corruption by disrupting parasitic } \\
\text { relationships }\end{array}$ & & $\begin{array}{l}\text { Syed et } \\
\text { al 2019 }\end{array}$ & $\mathrm{x}$ & \\
\hline Digitalization helped reduce corruption and fraud & & $\begin{array}{l}\text { Owusu- } \\
\text { Oware et } \\
\text { al 2018 }\end{array}$ & $\mathrm{x}$ & \\
\hline $\begin{array}{l}\text { ICT was used to reduce corruption and create a more "Weberian" } \\
\text { bureaucracy but with clear limits }\end{array}$ & & $\begin{array}{l}\text { Veerarag } \\
\text { han } \\
2013\end{array}$ & $\mathrm{x}$ & \\
\hline
\end{tabular}

Table 11: Effects of digitalization on corruption in developing countries

\section{Positive effects}

So far in the literature on digitalization and corruption there are no examples of positive unintended effects i.e., where technology users enact strategic capabilities of technology in ways that disrupt their corrupt practices beyond the expectations and objectives of technology implementers. Often, the interests of technology implementers (government officials, donors, senior managers etc.) are depicted as diametrically opposed to those of corrupt technology users. Intended positive effects also appear to be highly contingent and not common. They include reductions in government administration dysfunctions such as red tape that is associated with corrupt practices like 'speed money', the strengthening of formal processes to reduce shady practices (Senyo et al., 2019b; Veeraraghavan, 2013), constraining of corrupt behaviours by increasing transparency (Corojan \& Criado, 2012; Twinomurinzi, 2011), and disruption of corrupt practices and constituent networks (Syed \& Bandara, 2019). As most reported positive effects of digitalisation were intended or expected, future studies might yield interesting insights by exploring unintended effects of digitalization and how these manifest.

While there was insufficient evidence to assess the time range over which digitalization was considered, it is conceivable that short-term and longer-term observations might reveal differing effects (fewer positive effects in the short-term and more in the longer-term as digital technologies become more institutionalized and their benefits accumulate) (Addo, 2017).

\section{Negative effects}


Converse to our findings on positive effects, there are no examples of intended negative effects. Recorded negative effects involve the shifting of old forms of corruption to other areas or forms or the creation of new forms of corruption through digital technologies (Heeks, 1998). Corrupt actors might also follow designed processes in the short-run but relapse to old ways once monitoring is loosened or consultants leave the scene (Choudrie et al., 2017). Negative unintended effects of digitalization on corruption include emergence of new forms of virtual corruption (Addo \& Senyo, 2020), political wrangling and power struggles (Silva \& Hirschheim, 2007), victimization (Twinomurinzi, 2011), and mistargeting of root cause of corruption (Masiero, 2015; Masiero \& Prakash, 2015).

Though the literature points to unintended negative effects of digitalisation for anticorruption, there is limited knowledge on the intended (expected) effects and how these are prepared for. Given that awareness of potential negative effects is critical in digitalization project risk assessment and mitigation, it will be insightful to understand evidence of such manifestation. There is also insufficient evidence on the time dimension of anti-corruption digitalisation. Thus, there are still unanswered questions that require research attention about the unfolding over time of both the positive and negative effects of anti-corruption digitalization in developing countries.

\section{Agenda for Research}

Having traced the contours of the extant research on digitalization and government corruption in developing countries and highlighted outstanding issues, we proceed to outline a four-point agenda to extend the theoretical and empirical contributions in this area. To continue developing relevant insights for research and practice we suggest (1) clarifying links between anti-corruption strategies and digitalization (2) explicating how government corruption materializes and interacts with modalities of digitalization (3) uncovering digitalizationenabled capabilities and dynamic capabilities in the fight against corruption and (4) embracing 
methodological diversity to shed light on long-term processes, local perspectives and worldviews underpinning corruption and digitalization, as well as to bridge quantitative and qualitative work to provide novel approaches and empirics.

\subsection{Clarifying links between anti-corruption strategies and digitalization}

The literature on strategy has shown the relevance of having an IS strategy that is aligned with an overall organizational strategy (Karpovsky \& Galliers, 2015; Newkirk, Lederer, \& Johnson, 2008). While much of this work applies in business organizational contexts the merits of the alignment arguments are no less true for the public sector (Boudry \& Verdegem, 2012; Kim, Pan, \& Pan, 2007; Meijer \& Thaens, 2010). In the case of strategic digital technologies deployed in the fight against corruption, clear anti-corruption intentionality rendered through coherent strategies have been shown through the Singapore case to be essential. Nonetheless, not much is known about this aspect of digitalization and government corruption in developing countries, the range of strategies in use, their underlying conceptualizations, hypothesis of digitalization, motivating norms and values, or linkages to broader e-government strategies across the public sector as was the case in Singapore.

The process of anti-corruption strategy formulation also needs to be elucidated and the black box opened to reveal actors, interest and processes shaping such. In the developing country context where corruption is endemic this is especially important because the oftenmade assumption based on a principal-agent framing of corruption - that senior management/ government officials/citizens (who act as principals) are corruption-free and interested in curbing the opportunism of street-level bureaucrats (the agents) — does not necessarily apply. Principals may publicly or formally proffer an anti-corruption stance while acting (or not acting) to promote corruption privately and informally within networks that include corrupt agents. 
Finally, the dynamism of strategizing and aligning in practice needs to be explored in relation to digitalization and the feedback from the environment and anti-corruption effects. Given that corrupt actors are quick to learn and adapt to anti-corruption interventions, strategizing becomes akin to building a mouse trap, where constantly improving approaches are needed to outwit intelligent, constantly improving mice.

\subsection{Explicating materialization of government corruption and anti-corruption digitalization modalities}

Overall, the empirical base and theorizing on the topic of digitalization and government corruption in developing countries needs further development, greater conceptual clarity and better specification. More and different empirical studies (beyond the typical case studies or observational studies) of specific corruption practices in government organizations- their material configuration, actors, rationales and interactions with specific digitalization modalities of change (mechanisms) are needed to support novel middle-range theorizations. Such studies might benefit further from contextualist approaches that privilege the specificity of the developing country national and organizational contexts in shaping digitalization and corruption phenomena.

Organizationally, the mutual interactions between strategic capabilities of digital technologies/modalities of anti-corruption and their formative organizational structures require further exploration to better understand the potential of digitalization for deep structure changes that might render longer term transformation of corrupt practices (Addo, 2017; Silva \& Hirschheim, 2007). Similarly, better understanding of the mutual interactions between strategic capabilities of digital technologies and organizational barriers might inform actions to improve institutionalization of technologies in established practices and to overcome opposition to improvements. 
Regarding the broader context of developing countries, the literature on digitalization and corruption might usefully draw from other disciplines such as political economy and ethnography where the national context of developing countries in relation to corruption has been well-studied from historical and situated approaches to explain commonalities that underpin observations of the endemic nature of corruption and its endurance.

\subsection{Uncovering digitalization enabled capabilities and dynamic capabilities in the fight against corruption}

The literature suggests that anti-corruption interventions involving digitalization are different from normal strategic implementations because corruption cannot be directly observed and corrupt actors are quick to learn, adapt to, or sabotage interventions. This point begs the question of what specific capabilities and dynamic capabilities within government organizations are needed in the fight against corruption and what the role of digitalization is in enabling these. Though the literature provides anecdotal evidence of enhanced capabilities of digital technology to curb corruption, a number of questions remain unanswered that future studies may explore.

First, it is still unclear how dynamic capabilities of digital technologies are built and sustained to fight government corruption. For organisational survival, there is a requirement to build and maintain a host of dynamics (Schilke, Hu, \& Helfat, 2018). Moreover, corruption itself is a potent threat to organisational survival. Notwithstanding the contribution from prior IS studies, there is little knowledge within the government corruption literature on how digital dynamic capabilities are built and maintained in corruption contexts.

Second, there is limited understanding of how best digital technologies can be configured, integrated and implemented to curb government corruption. Given that corrupt actors find innovative ways to perpetuate corruption virtually in light of digitalization, is it important to understanding dynamic sociotechnical processes linked to capabilities of digital 
technologies. However, questions remain about how to identify, source and combine appropriate technology capabilities.

Lastly, there is an avenue for future research to explicate how context and cultural characteristics affect dynamic capabilities. Developing countries are characterised by sociocultural idiosyncrasies that are sometimes neglected in digitalisation projects (Al-Hujran, Al-dalahmeh, \& Aloudat, 2011; Ali, Weerakkody, \& El-Haddadeh, 2009). Though the extant literature has pointed out the effect of context in general (Avgerou, 2017; Avgerou \& Madon, 2004), there is limited understanding of how context and culture affects the identification, sourcing, development, and maintenance of digitally enabled dynamic capabilities in fighting corruption.

\subsection{Embracing methodological diversity}

The literature points to a dominance of observational and case studies based on variance accounts. Although these have some merits they are limited in not sufficiently unpacking interactions between digitalization and corruption as well as their unfolding processes over time. Given that public sector reforms generally take a long time to unfold (Chang, 2001; Schacter, 2000), variance-based case studies might be focusing on barely-noticeable momentin-time changes rather than noticeable longer term effects. Importantly, the central question of how corruption displaces after digitalization might be fruitfully explored with systematic studies of changes over time and at various levels of analysis - within work routines, processes, practices, work systems and entire organizations.

Corruption has also tended to be framed through western ethical and organizational lenses but more needs to be understood about the motivations of corrupt government actors and citizens in relation to the broader context of developing countries. Ethnographic approaches, such as individual, team and state ethnographies have potential to yield insights that can improve understandings of the normalization forces of corruption and the basis for 
their embeddedness in society even as socioeconomic conditions improve (Cantens, 2013; Cantens, Raballand, \& Bilangna, 2012; Chalfin, 2008; Street, 2012).

Finally, the evidence of positive anti-corruption effects of technology that is revealed in the observational studies literature (Shim \& Eom, 2008, 2009; Srivastava et al., 2016) must be reconciled with the overwhelming evidence of failed anti-corruption interventions suggested by in-depth case studies (Davis, 2004; Heeks, 1998; Masiero, 2015; Masiero \& Prakash, 2015; Silva \& Hirschheim, 2007). Such bridging of quantitative and qualitative studies might throw up novel approaches and evidence sources to explore wicked aspects of corruption such as its displacement and persistence.

\section{Limitations}

Although we have approached our study systematically, we have only focused on the debate from an IS (and sociotechnical) perspective. The topic is relevant in other disciplines and fields of study where it is framed and studied differently. For example, we have not considered a rich and growing body of work in Economics that makes different assumptions about the nature of digital technologies and employs a range of quantitative approaches or experimental methodologies such as randomized control trials (RCT) to explore corruption and anti-corruption determinants (e.g. the work of MIT's J-PAL program). Our findings and suggestions are therefore not generalizable beyond a defined scope of IS and related debates.

Second, we adopt a basic strategic perspective on digital technology as a starting point given that most anti-corruption interventions involve strategic information systems or some degree of strategic intent. Nonetheless, in view of our goal to synthesise the research and paint a coherent picture, we have had to trade off depth and breadth e.g. in terms of the level of detail in aspects of our analysis such as the strategic implications of digital technologies in the government administration of developing countries. Some of this work has been covered more 
richly elsewhere (Rabaiah \& Vandijck, 2009; Weerakkody, Janssen, \& Dwivedi, 2011; Xenakis \& Macintosh, 2005).

Third, while we made effort to exhaust the IS literature related to digitalization and corruption (by searching across the body of recognized IS journals and conferences), there were more publications that covered the topic outside the mainstream IS journals than within it. As such we were unable to trace the level of theoretical development/accumulation on the topic within IS as there were not many IS-specific studies in conversation with each other. Future studies might for instance conduct a meta-analysis of IS studies to assess the development of theory.

\section{Conclusions}

Our review of the IS and related research on digitalization and government corruption in developing countries points to a diverse and instructive body of work that is generally in need of further empirical and theoretical development. Given the multifaced and complex nature of government corruption, no single disciplinary approach or framing holds the key to unlocking the potential of digitalization for anti-corruption. Rather, multidisciplinary perspectives informed by sound and accumulated empirical evidence might have better chances of improving understanding on the topic.

As digital technologies continue to evolve, it is pertinent to continue exploring how their deployment and application might expand the range of possibilities for anti-corruption interventions in developing countries. More recent technologies like blockchain have been suggested to enable trust-free transactions without human or institutional intermediaries (Beck, Stenum Czepluch, Lollike, \& Malone, 2016). Possibilities of these and other technologies like artificial intelligence (AI) and social media might have significant developmental and anticorruption potential, although not in isolation. We believe our suggested agenda might help 
improve theoretical and practical capacity to effectively realize the potential of digital technologies in the fight against government corruption in developing countries.

\section{References}

Addo, A. 2016. Explaining "Irrationalities" of IT-Enabled Change in a Developing Country Bureaucracy: The Case of Ghana's TradeNet. Electronic Journal of Information Sytems in Developing Countries (EJISDC), 77(1): 1-22.

Addo, A. 2017. IT-enabled rationalization of public administration in developing countries: essays on Ghana's customs modernization. The London School of Economics and Political Science.

Addo, A. 2018. Controlling Government Corruption through IT : An Opportunity Theory Perspective. International Conference on Information Systems. San Francisco. Addo, A., \& Senyo, P. 2020. Does Process Reengineering and Digitalization Eliminate Corruption? Exploring "Paperless" Vehicle Clearance at Ghana's Port. Forthcoming. Al-Hujran, O., Al-dalahmeh, M., \& Aloudat, A. 2011. The Role of National Culture on Citizen Adoption of eGovernment Services: An Empirical Study. Electronic Journal of E-Government, 9(2): 93-106.

Ali, M., Weerakkody, V., \& El-Haddadeh, R. 2009. The Impact of National Culture on eGovernment Implementation: A Comparison Case Study. 15th Americas Conference on Information Systems (AMCIS 2009). San Francisco, CA: AIS.

Amankwah-sarfo, F., Boateng, R., \& Effah, J. 2018. Import Clearance Digitalization and Socioeconomic Development : The Case of Ghana, 1-10.

Andrews, M. 2012. The Logical Limits of Best Practice Administrative Solutions in

Developing Countries. Public Administration and Development, 32: 137-153. Anter, A. 2014. Max Weber's Theory of the Modern State: Origins, Structure and Significance. Palgrave Macmillan.

Antonsen, M., \& Beck Jørgensen, T. 1997. The "publicness” of public organizations. Public Administration, 75(2): 337-357.

Avgerou, C. 2001. The significance of context in information systems and organizational change. Information Systems Journal, 11(1): 43-63.

Avgerou, C. 2003. IT as an Institutional Actor in Developing Countries. In S. Krishna \& S. Madon (Eds.), The Digital Challenge: Information Technology in the Development Context: 46-62. Aldershot: Ashgate Publishing. Avgerou, C. 2017. Theoretical Framing of ICT4D Research. Proceedings of IFIP9.4 WG, 
$10-23$.

Avgerou, C. 2019. Contextual Explanation: Alternative Approaches and Persistent

Challenges. MIS Quarterly, 43(3).

Avgerou, C., \& Addo, A. 2017. Developmental Effects of the Digital Revolution. In R.

Galliers \& M.-K. Stein (Eds.), Critical Perspectives on Business and Management:

Management Information Systems. Routledge.

Avgerou, C., \& Madon, S. 2004. Framing IS studies: understanding the social context of IS

innovation. In C. Avgerou, C. Ciborra, \& F. Land (Eds.), The Social Study of

Information and Communication Technology: 162-182. New York: Oxford University Press.

Awofeso, O., \& Odeyemi, T. 2014. The impact of political leadership and corruption on

Nigeria's development since independence. Journal of Sustainable Development, 7(5).

Bardhan, P. 1997. Corruption and Development : A Review of Issues. Journal of Economic

Literature, 35(3): 1320-1346.

Beck, R., Stenum Czepluch, J., Lollike, N., \& Malone, S. 2016. Blockchain - the Gateway to Trust-Free Cryptographic Transactions. Twenty-Fourth European Conference on Information Systems (ECIS), İstanbul,Turkey, 2016.

Besson, P., \& Rowe, F. 2012. Strategizing information systems-enabled organizational transformation: A transdisciplinary review and new directions. Journal of Strategic Information Systems, 21(2): 103-124.

Bharadwaj, A., El Sawy, O., Pavlou, P., \& Venkatraman, N. 2013. Digital Business Strategy: Toward a Next Generation of Insights. MIS Quarterly, 37(2): 471-482.

Bhuiyan, S. 2011. Modernizing Bangladesh Public Administration through E-governance:

Benefits and Challenges. Government Information Quarterly, 28(1): 54-65.

Boudry, E., \& Verdegem, P. 2012. The Challenge of Technology: Alignment Dynamics in

Local Governments. Electronic Journal of Electronic Government, 10(2): 173-181.

Cantens, T. 2013. Other People's Money and Goods: the Relationship between Customs

Officers and Users in Some Countries of Sub-Saharan Africa. Sociologus, 63(1-2): 3758.

Cantens, T., Raballand, G., \& Bilangna, S. 2012. Reforming Customs by Measuring

Performance : a Cameroon Case Study. World Customs Journal, 4(2): 55-74.

Chalfin, B. 2008. Cars, the customs service, and sumptuary rule in neoliberal Ghana.

Comparative Studies in Society and History, 50(02): 424-453.

Chandler, A. 1962. Strategy and Structure: Chapters in the History of the American 
Industrial Enterprise. Cambridge, MA: MIT Press.

Chang, H.-J. 2001. Institutional Development in Developing Countries in a Historical

Perspective: Lessons from Developed Countries in Earlier Times. Siena, Italy.

Charoensukmongkol, P., \& Moqbel, M. 2014. Does Investment in ICT Curb or Create More

Corruption? A Cross-Country Analysis. Public Organization Review, 14(1): 51-63.

Choudrie, J., Zamani, E. D., Umeoji, E., \& Emmanuel, A. 2017. Implementing E-government in Lagos State: Understanding the impact of cultural perceptions and working practices. Government Information Quarterly, 34(4): 646-657.

Ciborra, C., \& Lanzara, G. 1994. Formative Contexts and Information Technology:

Understanding the Dynamics of Innovation in Organizations. Accounting, Management and Information Technologies, 4(2): 61-86.

Civil Service College (Singapore). 2015. Upholding Integrity in the Public Service.

Corbin, J. M., \& Strauss, A. 1990. Grounded theory research: Procedures, canons, and evaluative criteria. Qualitative Sociology, 13(1): 3-21.

Cordella, A., \& Iannacci, F. 2010. Information systems in the public sector: The eGovernment enactment framework. Journal of Strategic Information Systems, 19(1): $52-66$.

Corojan, A., \& Criado, J. 2012. E-government for transparency, anti-corruption, and accountability: Challenges and opportunities for Central American countries. Handbook of research on E-government in emerging economies: Adoption, E-participation, and legal frameworks: 328-330. Hershey, PA: IGI Global.

Damoah, I., Akwei, C., Amoako, I., \& Botchie, D. 2018. Corruption as a source of government project failure in developing countries: Evidence from Ghana. Project Management Journal, 49(3): 17-33.

Davis, J. 2004. Corruption in Public Service Delivery : Experience from South Asia's Water and Sanitation Sector. World Development, 32(1): 53-71.

de Graft, G. 2007. Causes of Corruption: Towards a Contextual Theory of Corruption. Public Administration Quarterly, 31(1): 39-44,46-86.

De Wulf, L. 2005. Tradenet in Ghana Best Practice of the Use of Information Technology.

Dehning, B., Richardson, V. J., \& Zmud, R. W. 2003. The Value Relevance of Announcements of Transformational Information Technology Investments. MIS Quarterly, 27(4): 637-656.

Effah, J. 2016. Institutional effects on E-payment entrepreneurship in a developing country: Enablers and constraints. Information Technology for Development, 22(2): 205-219. 
Ein-Dor, P., \& Segev, E. 1982. Organizational context and MIS structure: Some empirical evidence. MIS Quarterly, 6(3): 55-67.

Fountain, J. E. 2001. Building the Virtual State: Information Technology and Institutional Change. Washington DC: Brookings Institution Press.

Goundar, S. 2009. An Evaluation of Fiji 's E-Government Status : Assessed According to UN Report on Benchmarking E-Government Progress.

Guriev, S. 2004. Red Tape and Corruption. Journal of Development Economics, 73(2): 489504.

Ha, H. 2013. E-Government in Singapore: Critical Success Factors. In J. R. Gil-Garcia (Ed.), E-Government Success around the World: Cases, Empirical Studies, and Practical Recommendations: 176-197.

Hanna, N. K., \& Knight, P. T. 2012. National strategies to harness information technology:

Seeking transformation in Singapore, Finland, the Philippines, and South Africa.

Innovation, technology, and knowledge management. New York: Springer.

Hartnett, E. J., Daniel, E. M., \& Holti, R. 2012. Client and consultant engagement in public sector IS projects. International Journal of Information Management, 32(4): 307-317. Hasty, J. 2005. The Pleasures of Corruption: Desire and Discipline in Ghanaian Political Culture. Cultural Anthropology, 20(2): 271-301.

Hayes, N., \& Westrup, C. 2012. Context and the processes of ICT for development. Information and Organization, 22: 23-36.

Heeks, R. 1998. Information Technology and Public Sector Corruption. no. 4, Manchester. Hin, K. 2007. Corruption Control in Singapore - Effective National Anti-Corruption Strategies : Prosecuting High-Level Corruption, (October).

Hin, L. T. W., \& Subramaniam, R. 2005. E-Government: Implementation Policies and Best Practices from Singapore. In W. Huang, K. Siau, \& K. K. Wei (Eds.), Electronic Government Strategies and Implementation: 305-324. Hershey, PA: Idea Group Publishing.

Hopper, T. 2017. Neopatrimonialism, good governance, corruption and accounting in Africa: Idealism vs pragmatism. Journal of Accounting in Emerging Economies, 7(2): 225248.

Hull, M. 2012. Government of Paper: the Materiality of Bureaucracy of Urban Pakistan.

University of California Press.

Hunnius, S., \& Schuppan, T. 2013. Competency Requirements for Transformational EGovernment. 46th Hawaii International Conference on System Sciences (HICSS-46), 
0: 1664-1673. Wailea, HI, USA: IEEE Computer Society.

Joseph, R. 1987. Democracy and Prebendal Politics in Nigeria: The Rise and Fall of the

Second Republic. Cambridge University Press.

Joseph, R. 1996. Nigeria: Inside the Dismal Tunnel. Current History.

Karpovsky, A., \& Galliers, R. D. 2015. Aligning in practice: from current cases to a new

agenda. Journal of Information Technology, 30(2): 136-160.

Kim, H. J., Pan, G., \& Pan, S. L. 2007. Managing IT-enabled transformation in the public sector: A case study on e-government in South Korea. Government Information Quarterly, 24(2): 338-352.

Kim, S., \& Cho, K. 2005. Achieving Administrative Transparency Through Information Systems: A Case Study in the Seoul Metropolitan Government. In M. A. Wimmer, R. Traunmüller, Å. Grönlund, \& K. V Andersen (Eds.), Electronic Government: 4th International Conference (EGOV 2005), 3591: 113-123. Berlin / Heidelberg: Springer. Kim, S., Kim, H., \& Lee, H. 2009. An institutional analysis of an e-government system for anti-corruption: The case of OPEN. Government Information Quarterly, 26(1): 42-50.

King, J., \& Konsynski, B. 1995. Singapore TradeNet: A Tale of One City. Boston, MA:

Harvard Business School.

Klitgaard, R. 1991. Controlling Corruption. University of California Press.

Kock, N., \& Gaskins, L. 2013. Internet Diffusion and Government Corruption in Latin America and Sub-Saharan Africa. Proceedings of the 19th Americas Conference on Information Systems (AMCIS 2013).

http://aisel.aisnet.org/amcis2013/GlobalIssues/GeneralPresentations/6.

Kossow, N., \& Kukutschka, R. 2017. Civil society and online connectivity: controlling corruption on the net? Crime, Law and Social Change, 1-18.

Legner, C., Eymann, T., Hess, T., Matt, C., Bohman, T., et al. 2017. Digitalization :

Opportunity and Challenge for the Business and Information Systems Engineering Community. Business \& Information Systems Engineering, 59(4): 301-308.

Levy, M., Powell, P., \& Galliers, R. 1999. Assessing information systems strategy development frameworks in SMEs. Information \& Management, 36(5): 247-261. Lim Kah Hwee, N. 2016. Singapore's Experience in the Fight Against Corruption, 189195.

Locatelli, G., Mariani, G., Sainati, T., \& Greco, M. 2017. Corruption in public projects and megaprojects: There is an elephant in the room! International Journal of Project

Management, 35(3): 252-268. 
Masiero, S. 2015. Redesigning the Indian Food Security System through E-Governance: The Case of Kerala. World Development, 67: 126-137.

Masiero, S., \& Prakash, A. 2015. Does computerisation reduce PDS leakage?: Lessons from Karnataka. Economic and Political Weekly, 50(50): 77-81.

Meijer, A., \& Thaens, M. 2010. Alignment 2.0: Strategic use of new internet technologies in government. Government Information Quarterly, 27(2): 113-121.

Nawaz, F., \& Hodess, R. 2008. Corruption and resource distribution in neopatrimonial systems.

Neupane, A., Soar, J., \& Vaidya, K. 2012. The potential of e-procurement technology for reducing corruption. International Journal of Information Technology and Management, 11(4): 273-287.

Newkirk, H. E., Lederer, A. L., \& Johnson, A. M. 2008. Rapid business and IT change: drivers for strategic information systems planning? European Journal of Information Systems, 17(3): 198-218.

Njihia, J. M., \& Merali, Y. 2013. The Broader Context for ICT4D Projects: A Morphogenetic Analysis. MIS Quarterly, 37(3): 881-905.

O'Neil, T. 2007. Neopatrimonialism and public sector performance and reform. London.

Olken, B. a., \& Pande, R. 2012. Corruption in Developing Countries. Annual Review of Economics, 4: 479-509.

Orlikowski, W., \& Baroudi, J. 1991. Studying information technology in organizations: Research approaches and assumptions. Information Systems Research.

Owusu-oware, E., \& Boateng, R. 2018. Biometric Technology for Fighting Fraud in National Health Insurance: Ghana's Experience, 1-10.

Quah, J. 2001. Combating Corruption in Singapore: What Can Be Learned? Journal of Contingencies and Crisis Management, 9(1): 29-35.

Rabaiah, A., \& Vandijck, E. 2009. A Strategic Framework of e-Government: Generic and Best Practice. Electronic Journal of E-Government, 7(3): 241-258.

Ramasoota, P. 1998. Information Technology and Bureaucratic Surveillance: A case Study of the Population Information Network (PIN) in Thailand. Information Technology for Development, 8(1): 51-64.

Robinson, M. 1998. Corruption and development: An introduction. The European Journal of Development Research, 10(1): 1-14.

Saddler, P. F. 2007. Using Digital Hotlines in an Anti-Corruption Campaign. In A.-V. Anttiroiko \& M. Mälkiä (Eds.), Encyclopedia of digital government: 1595-1600. 
Hershey, PA: Idea Group Reference.

Sahay, S. 2008. The Dynamics of Corruption and ICT Projects : Case Study from the Public Health System in India.

Saint-Martin, D. 2000. Building the New Managerialist State: Consultants and the Politics of Public Sector Reform in Comparative Perspective. Oxford: Oxford University Press.

Sawyer, S., \& Jarrahi, M. 2014. Sociotechnical approaches to the study of Information

Systems. In H. Topi \& A. Tucker (Eds.), Computing Handbook (Third): 1-39. Boca Raton, FL: CRC Press.

Schacter, M. 2000. Public Sector Reform in Developing Countries Issues, Lessons and Future Directions. Ottawa.

Schilke, O., Hu, S., \& Helfat, C. 2018. Quo Vadis, Dynamic Capabilities? A ContentAnalytic Review of the Current State of Knowledge and Recommendations for Future Research. Academy of Management Annals, 12(1): 390-439.

Senyo, P. K., Liu, K., \& Effah, J. 2019a. Digital business ecosystem: Literature review and a framework for future research. International Journal of Information Management, 47: $52-64$.

Senyo, P. K., Liu, K., \& Effah, J. 2019b. Unpacking the Role of Political-Will in Digital Business Ecosystem Development for Socioeconomic Benefits. European Conference on Information Systems.

Shim, D., \& Eom, T. 2008. E-Government and Anti-Corruption : Empirical Analysis of International Data. International Journal of Public Administration, 31(3).

Shim, D., \& Eom, T. 2009. Anticorruption effects of information communication and technology (ICT) and social capital. International Review of Administrative Sciences, 75(1): 99-116.

Silal, P., Jha, A., \& Saha, D. 2019. From E - Government to Good Governance: The mediating role of Government E - Participation, (Heeks 2010): 1-17.

Silva, L., \& Hirschheim, R. 2007. Fighting Against Windmills: Strategic information Systems and Organizational Deep Structures. MIS Quarterly, 31(2): 327-354.

Singapore Customs and Corrupt Practices Investigation Bureau. 2018. Syndicate leader sentenced to five years and eight months' imprisonment and \$30m fine for smuggling duty-unpaid cigarettes and bribing Certis CISCO senior protection officer.

Srivastava, S., Teo, T., \& Devaraj, S. 2016. You Can’t Bribe a Computer: Dealing with the Societal Challenge of Corruption Through ICT. MIS Quarterly, 40(2): 511-526.

Stamati, T., Papadopoulos, T., \& Anagnostopoulos, D. 2015. Social media for openness and 
accountability in the public sector: Cases in the greek context. Government Information Quarterly, 32(1): 12-29.

Stapenhurst, F., \& Langseth, P. 1997. The role of the public administration in fighting corruption. International Journal of Public Sector Management, 10(5): 311-330.

Street, A. 2012. Seen by the state: Bureaucracy, visibility and governmentality in a Papua New Guinean hospital. Australian Journal of Anthropology, 23(1): 1-21.

Stremlau, N., Fantini, E., \& Gagliardone, I. 2015. Patronage, politics and performance: radio call-in programmes and the myth of accountability. Third World Quarterly, 36(8): $1510-1526$.

Suddaby, R. 2010. Editor's Comments: Construct Clarity in Theories of Management and Organization. Academy of Management, 35(3): 346-357.

Syed, R., \& Bandara, W. 2019. Controlling Corruption in Developing Country Public Sector : A Process Eco s ystems Perspective. International Conference on Information Systems 2019.

Teo, H.-H., Tan, B., \& Wei, K.-K. W. 1997. Organizational Transformation Using Electronic Data Interchange : the Case of TradeNet in Singapore. Journal of Management Information Systems, 13(4).

Twinomurinzi, H. 2011. Corruption in African Democratic Developing Countries and ICT : Apathy, Anxiety and Patriotism Corruption in African Democratic Developing.

Ufere, N., \& Carlson, B. 2012. Merchants of Corruption: How Entrepreneurs Manufacture and Supply Bribes. World Development, 40(12): 2440-2453.

United Nations. 2016. E-Government Survey. NewYork.

United Nations Development Program. 2008. Corruption and development. New York. Vaidya, R., Myers, Michael David, \& Myers, Michael D. 2017. Power in ICT4D projects : The case of an Indian Agricultural Marketing Board Power in ICT4D projects : The case of an Indian Agricultural Marketing Board, 0-17.

Veeraraghavan, R. 2013. Dealing with the digital panopticon: the use and subversion of ICT in an Indian bureaucracy. Proceedings of the Sixth International Conference on Information and Communication Technologies and Development Full Papers - ICTD '13 - volume 1, 248-255.

Vial, G. 2019. Journal of Strategic Information Systems Understanding digital transformation : A review and a research agenda. Journal of Strategic Information Systems, 28(2): 118-144.

von Soest, C. 2006. How Does Neopatrimonialism Affect the African State? The Case of 
Tax Collection in Zambia. no. 32, Hamburg.

Webster, J, \& Watson, R. 2002. Analyzing the Past to Prepare for the Future: Writing a Literature Review. MIS Quarterly, 26(2): xiii-xxiii.

Webster, Jane, \& Watson, R. T. 2002. Analyzing the Past to Prepare for the Future: Writing a Literature Review. MIS Quarterly, 26(2): xii-xxiii.

Weerakkody, V., Janssen, M., \& Dwivedi, Y. K. 2011. Transformational change and business process reengineering (BPR): Lessons from the British and Dutch public sector. Government Information Quarterly, 28(3): 320-328.

Wolfswinkel, J. F., Furtmueller, E., \& Wilderom, C. P. M. 2013. Using grounded theory as a method for rigorously reviewing literature. European Journal of Information Systems, 22: $45-55$.

World Bank Group. 1998. Corruption and development.

Xenakis, A., \& Macintosh, A. 2005. Using Business Process Re-engineering (BPR) for the Effective Administration of Electronic Voting. Electronic Journal of E-Government, 3(2): 91-98.

Yang, I., \& Wang, T. 2013. Singapore. Bribery \& Corruption: 160-166. 


\section{Appendices}

\section{Appendix 1: Details of research method}

Our grounded theory literature review approach comprised five stages and associated tasks (Table A1). In the subsections below, we outline how each stage was carried out.

Table A1: Grounded theory literature review approach

\begin{tabular}{|c|c|}
\hline Stages & Task(s) \\
\hline 1. Definition of review scope & $\begin{array}{l}\text { - Perform initial search to understand the literature coverage } \\
\text { - Define inclusion/exclusion criteria } \\
\text { - Identify sources } \\
\text { - Identify fields of research } \\
\text { - Establish search terms }\end{array}$ \\
\hline 2. Literature Search & - Perform the main search \\
\hline 3. Literature Selection & $\begin{array}{l}\text { - Apply the inclusion/exclusion criteria and identify additional sources } \\
\text { to produce the final sample } \\
\text { - Refine the sample }\end{array}$ \\
\hline 4. Analysis of corpus & $\begin{array}{l}\text { - Apply grounded theory coding techniques (open, axial and selective } \\
\text { coding) to analyze each selected article }\end{array}$ \\
\hline 5. Presentation of findings & $\begin{array}{l}\text { - Define structures to represent findings (e.g., tables, graphs) } \\
\text { - Define the structure of the review itself } \\
\text { - Write up the review }\end{array}$ \\
\hline
\end{tabular}

\section{Stage 1: Definition of review scope}

In this first stage, we defined the scope of the review by setting our boundaries. Our criteria was defined to consider only peer-reviewed journals and reputable conferences as these sources cover high-quality contributions on the topic (Webster \& Watson, 2002). We excluded dissertations, book reviews, books, as well as sources without full text and not in English.

In defining the scope of the review, we also performed an initial search in four databases, namely AIS Library, Scopus, Web of Science and Google Scholar so that we could understand coverage of literature and various conceptualisation of digitalization and corruption in relevant disciplines. These databases were selected because they host majority of IS and management journals and conferences. AIS library hosts leading IS journals and conferences while Scopus and Web of Science covers a significant range of peer-reviewed management journals. The findings from initial search show that our phenomenon of interest, "digitalization and corruption" transcends IS and other management disciplines. Therefore, we defined our scope to cover IS, Public Administration, Development and ICT4D, and General Management disciplines.

Our initial search also showed that different concepts such as "ICT", "information technology", "information systems" and "technology" have been used to investigate digitalization and corruption. Therefore, we defined our search terms to include different 
variations and combination of these keywords containing the terms "digitalization", "ICT", "information and communication technology", "information system", "information technology", "technology", "developing country" [as well as full list of named countries in that grouping as determined by the World Bank] and "corruption". Full list of search terms and dates are available from the authors.

\section{Stage 2: Literature search}

At this stage, we conducted the main literature search in the four databases based on the defined search protocol and keywords. We iteratively searched each of the four databases individually (our last search took place on $12^{\text {th }}$ December 2019). Our search was aided by the advanced search features in the selected databases. The searches were performed on the titles, abstracts and keywords to ensure only relevant article were retrieved. Given that the selected databases have difference search features, we had to adjust some of our search queries. For instance, in searching AIS Library (Figure A1), we only used the search term "corruption" on the title, abstract and subject (keyword) since this is an IS database that host studies related to digitalization. From the search results, we manually review the title and abstracts of each article and download the PDF and record any metadata such as authors details, title of publication, year and abstract in an Excel spreadsheet. These details are recorded to avoid duplication and ensure data integrity.

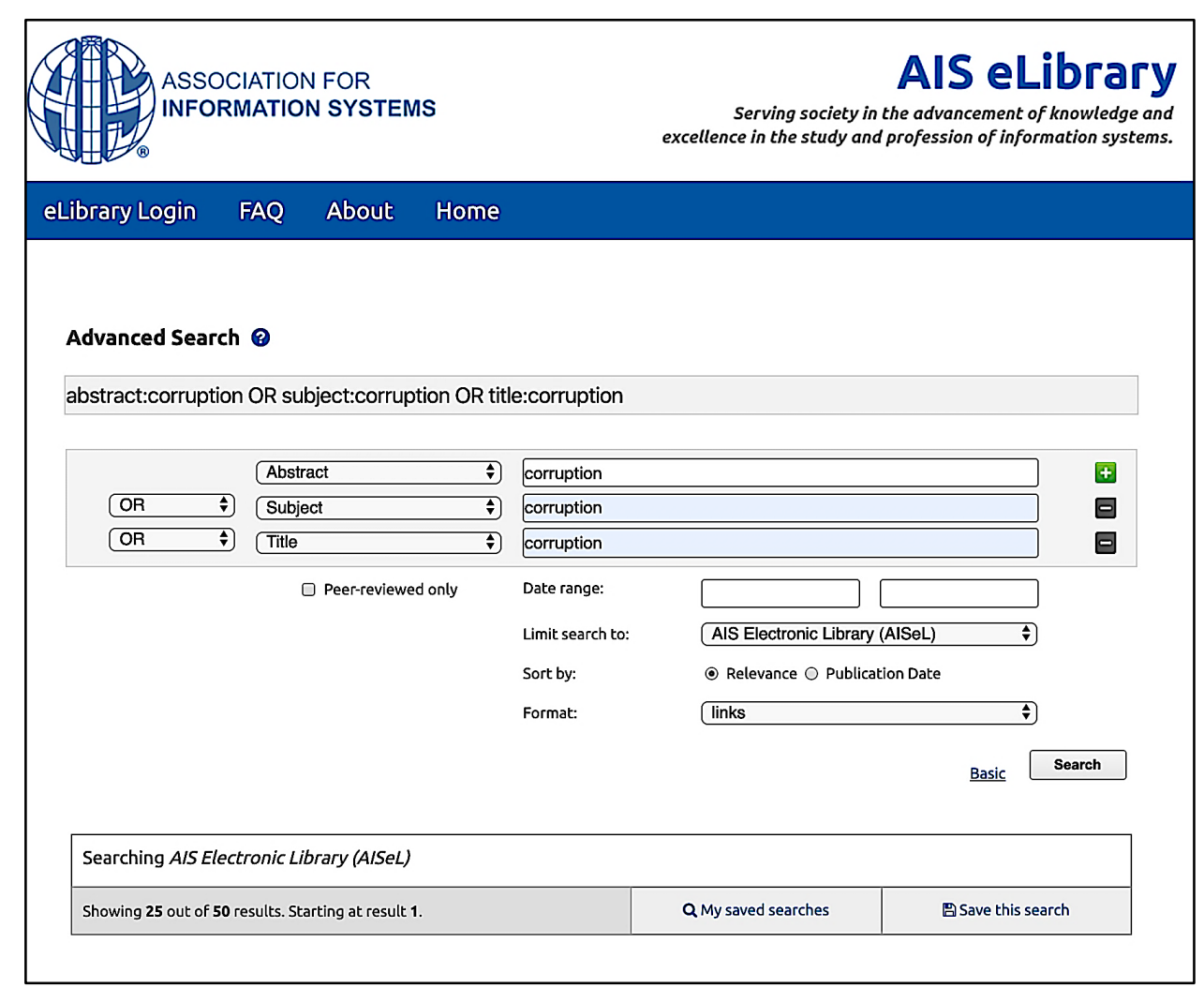

Figure A1: Literature search in AIS Library 


\section{Stage 3: Literature selection}

During this stage, we reviewed the literature corpus to select articles that are useful for the review. From an initial hit of 2,794 articles matching common keywords associated with digitalization, information technology, government, corruption, and developing countries, we manually reviewed each article based on our inclusion and exclusion criteria. For instance, we removed some articles that only used corruption as an example without discussion it into detail in the main article. Similarly, were also discarded articles that listed corruption as a keyword without further discussion in the main text. After applying our inclusion and exclusion criteria, we ended with 81 number of articles deemed useful for our review. We then performed forward and backword searches on the selected articles to ensure we do not unintentionally miss any useful article. This process resulting in additional 8 articles. Lastly, we for duplicates in the selected articles since searched multiple databases that index the same articles. After iteratively filtering and selecting appropriate articles for our review, we ended up with a final corpus of 90 highly relevant empirical studies.

\section{Stage 4: Analysis of corpus}

At this stage, we performed two main analysis. First, we performed descriptive analysis based on codes extracted from each article on elements, namely article title, author(s), publication outlet, publication year, publication outlet type (e.g., journal or conference proceedings), context of study (i.e. country of study), level of analysis (e.g., country, organization, group/team, department or individual), theoretical foundation, research method, research approach, as well as definition of government corruption and associated conceptual issues if any. The result of this analysis is presented in Appendix 2.

Second, we performed a more detailed analysis based on grounded theory techniques of open, axial and selective coding (Wolfswinkel et al., 2013). During this analysis, we thoroughly read each article in our corpus and developed open codes on the issues, focus, findings, discussion as well as other important elements in the first instance. For instance, open codes were extracted on the expectation of digitalization in anti-corruption, nature of anticorruption strategy, expected outcomes of digitalization and if outcomes were intended as well as digitalization processes (pre-implementation/post-implementation) among others. In line with tenets of grounded theory, we iteratively coded elements from each article to gradually discover salient excerpts that are useful to our review (Corbin \& Strauss, 1990).

Following this, we analysed the conceptual similarity of the open codes to generate axial codes by iteratively mapping and integrating the code excerpts. For instance, open codes such as "IT lowers transaction costs which reduces corruption" and "IT enables improved 
business processes which leads to reduction in corruption" on the expectation of digitalization technology effects on corruption in developing countries were integrated to generate an axial code labelled "Connectivity". In line with the grounded theory coding and analysis technique, we performed several iterations between the open codes, articles corpus and the axial codes.

Lastly, we performed selective coding by iteratively analysing and refining the axial codes (Corbin \& Strauss, 1990). The selective coding process led us to generated high-order codes that formed the foundation for the framework of digitalization and government corruption in developing countries. Given that the selective codes only present issues at a highlevel, we ensure that our framework captures lower-level open and axial codes to present a clearer understanding of the relationships between key concepts underpinning our review.

\section{Stage 5: Presentation of Findings}

In this last stage, we presented the findings from the review in the main article and in Appendices 2 and 3. The findings were presented in the main article under three major headings: (1) defining government corruption, (2) expectation of digitalisation in anticorruption and (3) framework of digitalization and government corruption in developing countries. The findings presented in Appendix 2 cover descriptive statistics such as publication outlet, level of analysis, publication year, publication outlet type, context of study, level of analysis, theoretical foundation, and research methods on selected article in our corpus. Lastly, Appendix 3 presents the full list of articles used in our review.

\section{References}

Corbin, J. M., \& Strauss, A. (1990). Grounded theory research: Procedures, canons, and evaluative criteria. Qualitative sociology, 13(1), 3-21.

Webster, J., \& Watson, R. T. 2002. Analyzing the Past to Prepare for the Future: Writing a Literature Review. MIS Quarterly, 26(2): xii-xxiii. 


\section{Appendix 2 - Descriptive Statistics of Studies on Digitalization and Government Corruption in Developing Countries}

This appendix presents descriptive statistics on articles reviewed in this study. As presented in Figure A2.1, studies on digitalisation and government corruption transcend micro, meso and macro levels. However, the majority of studies are at the macro cross-country level $(n=38)$, followed by national $(n=25)$ and organisational $(n=15)$ levels. The dominance of cross-country studies is attributed to the frequent use of corruption perception index secondary data in majority of articles.

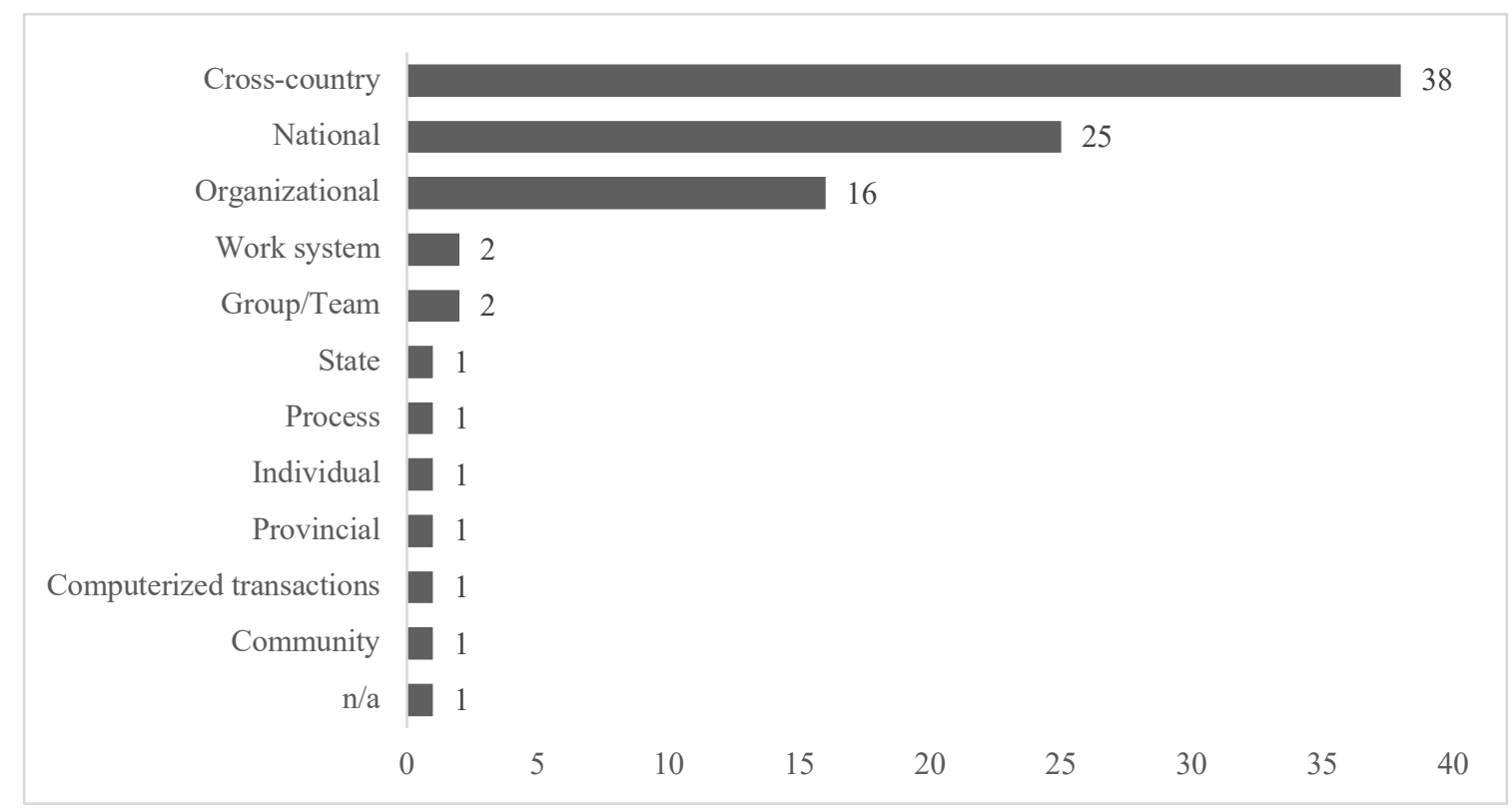

Figure A2.1: Level of analysis of the literature review

Figure A2.2 presents distribution of studies reviewed in terms of primary research themes.

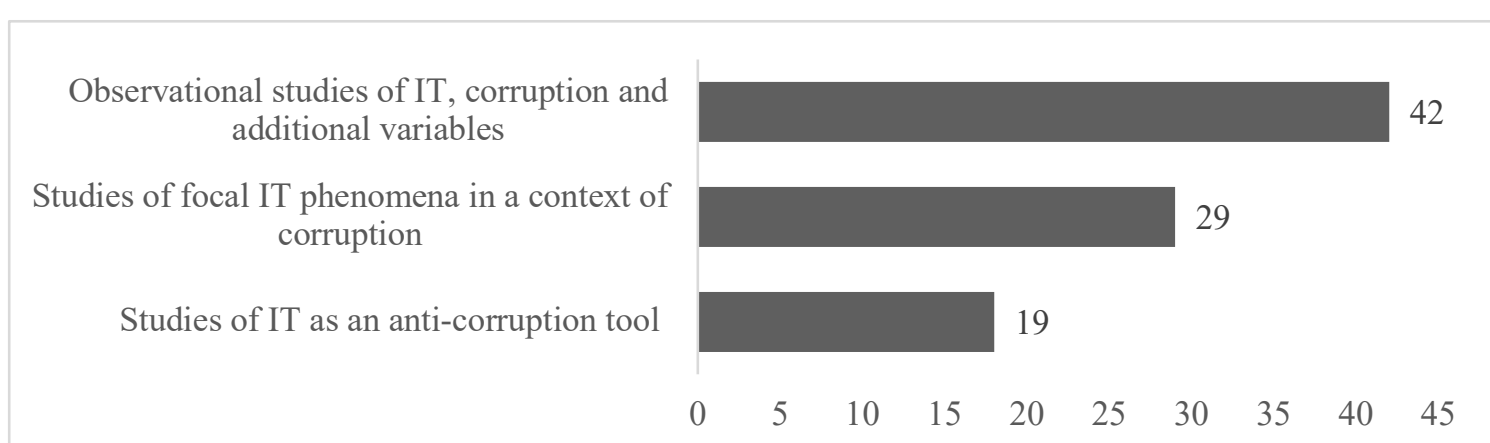

Figure A2.2: Primary research themes of the literature review

Majority of articles belong to the observational studies of IT $(n=42)$ which considered corruption at the national or cross-country level with less specificity on the range of corruption types at stake or their materialization in specific settings. This theme is followed by studies of focal IT phenomena in a context of corruption $(n=29)$ which investigated corruption at the 
organisational, national, group/team, transactions, individual, state and process levels. Lastly, articles in the studies of IT as an anti-corruption tool theme $(n=19)$ considered individuals and their practices, corruption within group and teams, corruption at the level of work process, within particular government administrations/agencies, across government administrations/agencies or at the societal level.

In terms of research methodologies used in the articles reviewed, the findings as presented in Figure A2.3 show that majority of studies used the quantitative methodology $(n=48)$, followed by the qualitative $(n=24)$, conceptual studies $(n=13)$ and mixed method $(n=2)$ and design research $(n=2)$. Given that majority of the studies reviewed used secondary data for crosscountry analysis, this result was not surprising. However, to ensure a holistic understanding of digitalisation and government corruption, there is a need for more qualitative, mixed methods and design studies.

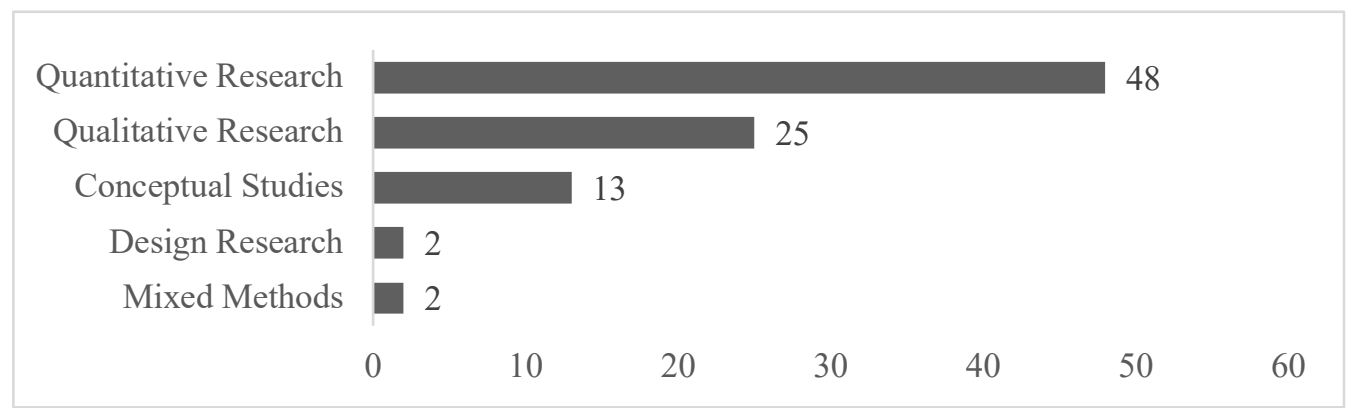

Figure A2.3: Research methodologies used in the literature review

The review shows mixed trends with regards to yearly distribution of articles (see Figure A2.4). Though studies on digitalisation and government corruption within our areas of focus were published from the year $1998(n=2)$ to $2019(n=3)$, some years $(1999,2000,2001,2002,2003$, 2006) witnessed no publications. On the other hand, the years $2017(n=10), 2015(n=9)$ and $2014(\mathrm{n}=9)$ witnessed more studies. Though the overall number of studies on digitalization and government corruption is notable, there is need for more research given the strategic nature of this area.

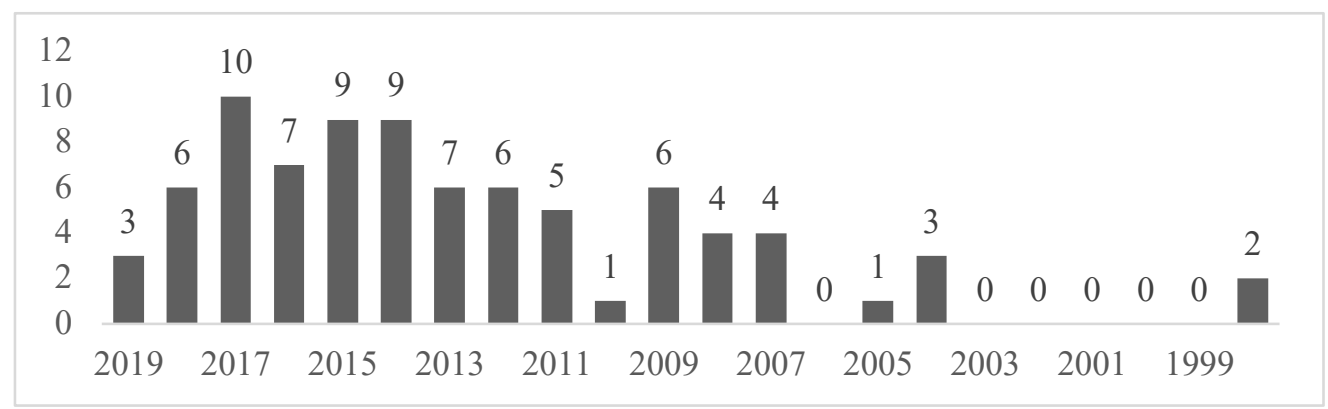

Figure A2.4: Yearly distribution of literature review 


\section{Appendix 3 - List of studies reviewed}

\begin{tabular}{|c|c|c|}
\hline Study & Publication & Paper title \\
\hline \multicolumn{3}{|r|}{ Journal Articles } \\
\hline Abu-Shanab et al. 2013 & $\begin{array}{l}\text { International Journal of Electronic } \\
\text { Governance }\end{array}$ & E-government as an anti-corruption tool: citizens perception \\
\hline Addo 2016 & $\begin{array}{l}\text { Electronic Journal of Information } \\
\text { Systems in Developing Countries }\end{array}$ & Explaining 'irrationalities' of it-enabled change in a developing country bureaucracy: The case of Ghana's TradeNet \\
\hline Ameen and Ahmad 2013 & $\begin{array}{l}\text { Journal of Theoretical and Applied } \\
\text { Information Technology }\end{array}$ & A Framework of Financial Information Systems to Reduce Corruption \\
\hline Andersen 2009 & Information Economics and Policy & E-Government as an anti-corruption strategy \\
\hline Bailard 2009 & Political Communication & Mobile Phone Diffusion and Corruption in Africa \\
\hline Berman and Tettey 2001 & Public Administration \& Development & African states, bureaucratic culture and computer fixes \\
\hline $\begin{array}{l}\text { Bhattacherjee and } \\
\text { Shrivastava } 2018\end{array}$ & Government Information Quarterly & The effects of ICT use and ICT Laws on corruption: A general deterrence Theory perspective \\
\hline Bhuiyan 2011 & Government Information Quarterly & Modernizing Bangladesh public administration through e-governance: Benefits and challenges \\
\hline $\begin{array}{l}\text { Charoensukmongkol and } \\
\text { Mogbel } 2014\end{array}$ & Public Organization Review & Does Investment in ICT Curb or Create More Corruption? A Cross-Country Analysis \\
\hline Cho and Choi 2004 & $\begin{array}{l}\text { International Journal of Public } \\
\text { Administration }\end{array}$ & E-Government to Combat Corruption: The Case of Seoul Metropolitan Government \\
\hline Choi 2014 & World Political Science Review & E-Government and Corruption: A Cross-Country Survey \\
\hline Choudrie et al. 2017 & Government Information Quarterly & Implementing E-government in Lagos State: Understanding the impact of cultural perceptions and working practices \\
\hline Davis 2004 & World Development & Corruption in Public Service Delivery: Experience from South Asia's Water and Sanitation Sector \\
\hline DiRienzo et al. 2007 & $\begin{array}{l}\text { Journal of International Business } \\
\text { Studies }\end{array}$ & Corruption and the role of information \\
\hline Elbahnasawy 2014 & World Development & E-Government, Internet Adoption, and Corruption: An Empirical Investigation \\
\hline Garcia-Murillo 2013 & $\begin{array}{l}\text { Information Technology for } \\
\text { Development }\end{array}$ & Does a government web presence reduce perceptions of corruption? \\
\hline Heeks 1998 & $\begin{array}{l}\text { Information Technology and Public } \\
\text { Sector Corruption }\end{array}$ & Information Technology and Public Sector Corruption \\
\hline Introna et al. 2010 & $\begin{array}{l}\text { International Journal of Public } \\
\text { Administration }\end{array}$ & The Working Out of Modernization in the Public Sector: The Case of an E-government Initiative in Greece \\
\hline Jha and Sarangi 2017 & Information Economics and Policy & Does social media reduce corruption? \\
\hline Kanyam et al. 2017 & World Development & The Mobile Phone Revolution: Have Mobile Phones and the Internet Reduced Corruption in Sub-Saharan Africa? \\
\hline Kim 2014 & Public Organization Review & Anti-Corruption Initiatives and E-Government: A Cross-National Study \\
\hline Kim et al. 2009 & Government Information Quarterly & An institutional analysis of an e-government system for anti-corruption: The case of OPEN \\
\hline Kock and Gaskins 2014 & $\begin{array}{l}\text { Information Technology for } \\
\text { Development }\end{array}$ & $\begin{array}{l}\text { The Mediating Role of Voice and Accountability in the Relationship Between Internet Diffusion and Government Corruption in Latin America and } \\
\text { Sub-Saharan Africa }\end{array}$ \\
\hline $\begin{array}{l}\text { Kossow and Kukutschka } \\
2017\end{array}$ & Crime, Law, and Social Change & Civil society and online connectivity: controlling corruption on the net? \\
\hline Kovacic 2005 & $\begin{array}{l}\text { International Journal of Electronic } \\
\text { Governance }\end{array}$ & A Brave New E-World? An Exploratory Analysis of Worldwide E-Government Readiness, Level of Democracy, Corruption and Globalization \\
\hline Krishnan et al. 2013 & Information and Management & Examining the relationships among e-government maturity, corruption, economic prosperity and environmental degradation: A cross-country analysis \\
\hline
\end{tabular}




\begin{tabular}{|c|c|c|}
\hline Lee and Lio 2016 & \begin{tabular}{|l|l} 
Information Development \\
\end{tabular} & The impact of information and communication technology on public governance and corruption in China \\
\hline Lio et al. 2011 & Government Information Quarterly & Can the internet reduce corruption? A cross-country study based on dynamic panel data models \\
\hline Mahmood 2004 & $\begin{array}{l}\text { Perspectives on Global Development } \\
\text { and Technology }\end{array}$ & Can Information and Communication Technology Help Reduce Corruption? How So and Why Not: Two Case Studies from South Asia \\
\hline Masiero 2015 & \begin{tabular}{|l|l} 
World Development \\
\end{tabular} & Redesigning the Indian Food Security System through E-Governance: The Case of Kerala \\
\hline Mistry 2012 & Accounting and the Public Interest & The Role of e-Governance in Mitigating Corruption \\
\hline Mistry and Jalal 2012 & $\begin{array}{l}\text { The International Journal of Digital } \\
\text { Accounting Research } \\
\end{array}$ & An Empirical Analysis of the Relationship between e-government and Corruption \\
\hline Nam 2018 & Government Information Quarterly & Examining the anti-corruption effect of e-government and the moderating effect of national culture: A cross-country study \\
\hline Neupane et al. 2012 & \begin{tabular}{|l|} 
Electronic Journal of Information \\
Systems in Developing Countries
\end{tabular} & Evaluating the anti-corruption capabilities of public e-procurement in a developing country \\
\hline $\begin{array}{l}\text { Neupane, Soar, and } \\
\text { Vaidya } 2014\end{array}$ & $\begin{array}{l}\text { Australasian Journal of Information } \\
\text { Systems }\end{array}$ & Evaluating the anti-corruption capabilities of public e-procurement in a developing country \\
\hline $\begin{array}{l}\text { Neupane, Soar, and } \\
\text { Vaidya } 2015\end{array}$ & $\begin{array}{l}\text { Business Law and Ethics: Concepts, } \\
\text { Methodologies, Tools, and } \\
\text { Applications }\end{array}$ & Anti-Corruption Capabilities of Public E-Procurement Technologies: Principal-Agent Theory \\
\hline Oni 2016 & $\begin{array}{l}\text { Design Solutions for User-Centric } \\
\text { Information Systems }\end{array}$ & $\begin{array}{l}\text { E-Government adoption in } \\
\text { Nigeria and the Journey So Far: The End of Corruption? }\end{array}$ \\
\hline Pathak et al. 2009 & $\begin{array}{l}\text { International Journal of Public } \\
\text { Administration }\end{array}$ & E-Governance to Cut Corruption in Public Service Delivery: A Case Study of Fiji \\
\hline Peterson 1998 & Public Administration \& Development & Saints, demons, wizards and systems: why information technology reforms fail or underperform in public bureaucracies in Africa \\
\hline $\begin{array}{l}\text { Prasad and Shivarajan } \\
2015\end{array}$ & Journal of Public Affairs & Understanding the role of technology in reducing corruption: a transaction cost approach \\
\hline Ramasoota 1998 & $\begin{array}{l}\text { Information Technology for } \\
\text { Development }\end{array}$ & Information technology and bureaucratic surveillance \\
\hline Relly 2012 & Government Information Quarterly & Examining a model of vertical accountability: A cross-national study of the influence of information access on the control of corruption \\
\hline Sassi and Ben Ali 2017 & Telecommunications Policy & Corruption in Africa: What role does ICT diffusion play \\
\hline Saxena 2017 & Foresight & Factors influencing perceptions on corruption in public service delivery via e-government platform \\
\hline Shim and Eom 2008 & $\begin{array}{l}\text { International Journal of Public } \\
\text { Administration }\end{array}$ & E-Government and Anti-Corruption: Empirical Analysis of International Data \\
\hline Shim and Eom 2009 & $\begin{array}{l}\text { International Review of Administrative } \\
\text { Sciences }\end{array}$ & Anticorruption effects of information communication and technology (ICT) and social capital \\
\hline $\begin{array}{l}\text { Silva and Hirschheim } \\
2007\end{array}$ & MIS Quarterly & Fighting against windmills: Strategic information systems and organizational deep structures \\
\hline Srivastava et al. 2016 & MIS Quarterly & You Can't bribe a computer: Dealing with the societal challenge of corruption through ICT \\
\hline Stamati et al. 2015 & Government Information Quarterly & Social media for openness and accountability in the public sector: Cases in the Greek context \\
\hline Stremlau et al. 2015 & Third World Quarterly & Patronage, politics and performance: radio call-in programmes and the myth of accountability \\
\hline Valle-Cruz et al. 2016 & Information Polity & Citizens' perceptions of the impact of information technology use on transparency, efficiency and corruption in local governments \\
\hline Xinli 2015 & Electronic Library & Effectiveness of information technology in reducing corruption in China: A validation of the DeLone and McLean information systems success model \\
\hline Zhao and Xu 2015 & $\begin{array}{l}\text { International Journal of Public } \\
\text { Administration }\end{array}$ & E-Government and Corruption: A Longitudinal Analysis of Countries \\
\hline \multicolumn{3}{|r|}{ Conferences Articles } \\
\hline Addo 2018 & $\begin{array}{l}\text { International Conference on } \\
\text { Information Systems }\end{array}$ & Controlling Government Corruption through IT: An Opportunity Theory Perspective \\
\hline
\end{tabular}




\begin{tabular}{|l|l|}
\hline Alryalat at al 2013 & UK Academy for Information Systems \\
\hline $\begin{array}{l}\text { Amankwah-Safo et al } \\
2018\end{array}$ & $\begin{array}{l}\text { Americas Conference on Information } \\
\text { Systems }\end{array}$ \\
\hline Bellini 2014 & $\begin{array}{l}\text { Mediterranean Conference on } \\
\text { Information Systems }\end{array}$ \\
\hline Goundar 2009 & GlobDev \\
\hline Hope and Korpoe 2011 & $\begin{array}{l}\text { Americas Conference on Information } \\
\text { Systems }\end{array}$ \\
\hline Khan and Krishnan 2018 & $\begin{array}{l}\text { Pacific Asia Conference on Information } \\
\text { Systems }\end{array}$ \\
\hline Kock and Gaskins 2013 & $\begin{array}{l}\text { Americas Conference on Information } \\
\text { Systems }\end{array}$ \\
\hline Krishnan and Teo 2012 & $\begin{array}{l}\text { International Conference on } \\
\text { Information Systems }\end{array}$ \\
\hline Krishnan et al 2012 & $\begin{array}{l}\text { Pacific Asia Conference on Information } \\
\text { Systems }\end{array}$ \\
\hline Martinez 2015 & $\begin{array}{l}\text { 2015 International Conference on } \\
\text { Information Systems }\end{array}$ \\
\hline Mimbi and Bankole 2016 & $\begin{array}{l}\text { ACM International Conference } \\
\text { Proceeding Series }\end{array}$ \\
\hline Nugroho 2014 & $\begin{array}{l}\text { Proceedings of the European } \\
\text { Conference on e-Government, ECEG }\end{array}$ \\
\hline Owusu-Oware et al 2018 & $\begin{array}{l}\text { Americas Conference on Information } \\
\text { Systems }\end{array}$ \\
\hline Palvia et al 2017 & $\begin{array}{l}\text { Americas Conference on Information } \\
\text { Systems }\end{array}$ \\
\hline Pankowska 2017 & $\begin{array}{l}\text { International Conference on } \\
\text { Information Systems Development }\end{array}$ \\
\hline Priyatman 2008 & $\begin{array}{l}\text { Pacific Asia Conference on Information } \\
\text { Systems }\end{array}$ \\
\hline Raghupathi and Wu 2011 & $\begin{array}{l}\text { Communications of the Association for } \\
\text { Information Systems }\end{array}$ \\
\hline Rana et al 2013 & UK Academy for Information Systems \\
\hline Rana et al 2014 & UK Academy for Information Systems \\
\hline Sahay and Puri 2008 & $\begin{array}{l}\text { International Conference on } \\
\text { Information Systems }\end{array}$ \\
\hline Selke et al. 2008 & $\begin{array}{l}\text { Proceedings of the European } \\
\text { Conference on e-Government, ECEG }\end{array}$ \\
\hline Senyo et al 2019 & $\begin{array}{l}\text { European Conference on Information } \\
\text { Systems }\end{array}$ \\
\hline Seo and Warman 2011 & $\begin{array}{l}\text { International Conference on } \\
\text { Information Systems }\end{array}$ \\
\hline Shrivastava and \\
Bhattacherjee 2014 & $\begin{array}{l}\text { Americas Conference on Information } \\
\text { Systems, AMCIS 2014 }\end{array}$ \\
\hline $\begin{array}{l}\text { Shrivastava and } \\
\text { Bhattacherjee 2015 }\end{array}$ & $\begin{array}{l}\text { Americas Conference on Information } \\
\text { Systems, AMCIS 2015 }\end{array}$ \\
\hline Silal et al 2019 & $\begin{array}{l}\text { International Conference on } \\
\text { Information Systems }\end{array}$ \\
\hline Soper 2007 Information \\
\hline
\end{tabular}

EXAMINING ROLE OF USEFULNESS, EASE OF USE AND SOCIAL INFLUENCE ON JORDANIAN CITIZEN'S INTENTION TO ADOPT E-

Import Clearance Digitalization and Socioeconomic Development: A Case Study of Ghana

Big Data Analytics for Financial Frauds Detection

An Evaluation of Fiji's E-Government Status: Assessed According to UN Report on Benchmarking E-Government Progress The Effects of ICT Pervasiveness on Administrative Corruption

Corruption in National Institutions and E- Government Maturity: Insights from Cross- Country Data Internet Diffusion and Government Corruption in Latin America and Sub-Saharan Africa

Does Governance Matter? Investigating the Impact of Governance on e-Government Maturity

E-Government Maturity, Corruption, And Eco- Efficiency

Transparency in Brazil: Why Has it Failed to Curb Corruption?

Factors Influencing ICT Service Efficiency in Curbing Corruption in Africa: A Bootstrap Approach

Electronic Government Procurement Adoption in Developing Economies: How Corruption Influence System's Adoption

Biometric Technology for Fighting Fraud in National Health Insurance: Ghana's Experience

Imperatives and Challenges in using E- Government to Combat Corruption: A Systematic Review of Literature and a

Holistic Model

Business Strategy Analytics

作

The Relationship Between Information and Communication Technologies and Country Governance: An Exploratory Study

Examining Factors Affecting Adoption of Online Public Grievance Redressal System: A Case of India

Measuring Intention to use and Satisfaction with Electronic District System: Validation of a combined Model of IS Success

The Dynamics of Corruption and ICT Projects: Case Study from the Public Health System in India

E-Honesty: Technical potentials and social risks of local e-government strategies in Bangladesh for supporting the fight against corruption

Unpacking the role of Political-will in Digital Business Ecosystem Development for Socioeconomic Benefits

User Satisfaction of E-government Procurement Systems in Developing Countries: An Empirical Research in

ICT Development and Corruption: An Empirical Study

ICT as a Corruption Deterrent: A Theoretical Perspective

From E-Government to Good Governance:

mediating role of Government E-Participation

ICT Investment Impacts on Future Levels of Democracy, Corruption, and E-Government Acceptance in Emerging Countries 


\begin{tabular}{|l|l|l|}
\hline Srivastava et al 2007 & $\begin{array}{l}\text { International Conference on } \\
\text { Information Systems }\end{array}$ & E-Government and Corruption: A Cross-Country Analysis \\
\hline Syed et al 2019 & $\begin{array}{l}\text { International Conference on } \\
\text { Information Systems }\end{array}$ & Controlling Corruption in Developing Country Public Sector: A Process Eco-Systems Perspective \\
\hline Therese and Azwe 2016 & $\begin{array}{l}\text { Americas Conference on Information } \\
\text { Systems }\end{array}$ & Youth Policy and the Future of Africa's Development: Exploring the Potential Contribution of ICT in the Youth Empowerment Process in Cameroon \\
\hline Twinomurinzi et al 2011 & GlobDev & Corruption in African Democratic Developing Countries and ICT: Apathy, Anxiety and Patriotism \\
\hline Vaidya and Myers 2017 & $\begin{array}{l}\text { International Conference on } \\
\text { Information Systems }\end{array}$ & Power in ICT4D projects: The case of an Indian Agricultural Marketing Board \\
\hline Veeraraghavan 2013 & $\begin{array}{l}\text { ICTD '13: Proceedings of the Sixth } \\
\text { International Conference on } \\
\text { Information and Communication } \\
\text { Technologies and Development }\end{array}$ & Dealing with the digital panopticon: the use and subversion of ICT in an Indian bureaucracy \\
\hline Walle at al 2018 & $\begin{array}{l}\text { European Conference on Digital } \\
\text { Government }\end{array}$ & Fighting Administrative Corruption with Digital Government in Sub- Saharan Africa \\
\hline Zhao et al. 2017 & $\begin{array}{l}\text { ACM International Conference } \\
\text { Proceeding Series }\end{array}$ & E-government, corruption reduction and culture: a study based on panel data of 57 countries \\
\hline \multicolumn{2}{|l|}{ Chapter } \\
\hline Corojan and Criado 2012 & $\begin{array}{l}\text { Handbook of research on E- } \\
\text { government in emerging economies: } \\
\text { Adoption, E-participation, and legal } \\
\text { frameworks }\end{array}$ & E-Government for Transparency, Anti-Corruption, and Accountability: Challenges and Opportunities for Central American Countries \\
\hline
\end{tabular}

